\title{
Monosubstituted Acetophenone Thiosemicarbazones as Potent Inhibitors of Tyrosinase: Synthesis, Inhibitory Studies, and Molecular Docking
}

\author{
Katarzyna Hałdys ${ }^{1, *}$, Waldemar Goldeman ${ }^{2}$, Natalia Anger-Góra ${ }^{3} \mathbb{D}$, Joanna Rossowska ${ }^{3}$ and Rafał Latajka ${ }^{1, *}$ \\ 1 Department of Bioorganic Chemistry, Wrocław University of Science and Technology, 50-370 Wrocław, Poland \\ 2 Department of Organic and Medicinal Chemistry, Wrocław University of Science and Technology, \\ 50-370 Wrocław, Poland; waldemar.goldeman@pwr.edu.pl \\ 3 Ludwik Hirszfeld Institute of Immunology and Experimental Therapy, Polish Academy of Science, \\ 53-114 Wrocław, Poland; natalia.anger@hirszfeld.pl (N.A.-G.); joanna.rossowska@hirszfeld.pl (J.R.) \\ * Correspondence: katarzyna.haldys@pwr.edu.pl (K.H.); rafal.latajka@pwr.edu.pl (R.L.)
}

check for updates

Citation: Hałdys, K.; Goldeman, W.; Anger-Góra, N.; Rossowska, J.;

Latajka, R. Monosubstituted Acetophenone Thiosemicarbazones as Potent Inhibitors of Tyrosinase: Synthesis, Inhibitory Studies, and Molecular Docking. Pharmaceuticals 2021, 14, 74. https://doi.org/ $10.3390 /$ ph14010074

Received: 16 December 2020

Accepted: 11 January 2021

Published: 18 January 2021

Publisher's Note: MDPI stays neutral with regard to jurisdictional claims in published maps and institutional affiliations.

Copyright: (c) 2021 by the authors. Licensee MDPI, Basel, Switzerland. This article is an open access article distributed under the terms and conditions of the Creative Commons Attribution (CC BY) license (https:/ / creativecommons.org/licenses/by/ $4.0 /)$.

\begin{abstract}
A set of 12 monosubstituted acetophenone thiosemicarbazone derivatives (TSCs) were synthesized and their inhibitory properties toward tyrosinase activity were tested. Moreover, their ability to inhibit melanogenesis in the B16F10 murine melanoma cell line was studied. In order to investigate the nature of interactions between the enzyme and the inhibitors, molecular docking to the active site was performed. TSCs 5, 6, 8, and 9 revealed a half maximal inhibitory concentration $\left(\mathrm{IC}_{50}\right)$ below $1 \mu \mathrm{M}$. Compound 6 turned out to be the most potent tyrosinase inhibitor. All investigated compounds showed reversible inhibition of competitive or mixed type. The para-substituted TSCs had higher affinity for the enzyme as compared to their ortho- and meta-analogues. All investigated compounds inhibited melanin production in B16F10 cells at the micromolar level. Molecular docking showed that the sulfur atom of the thiourea moiety penetrates the active site and interacts with copper ions. The above outcomes might be helpful in the design of new tyrosinase inhibitors in the food and cosmetic industries.
\end{abstract}

Keywords: tyrosinase; thiosemicarbazones; kinetic studies; structure-activity relationship (SAR); molecular docking; melanogenesis

\section{Introduction}

Tyrosinase belongs to the oxidoreductase family (EC 1.14.18.1). There are two copper atoms in its active site which are important for catalytic activity [1]. Tyrosinase can catalyze two different reactions. The first is oxidation of monophenols to ortho-quinones and the second is oxidation of ortho-diphenols (catechols) to ortho-quinones [2].

Melanins are pigments widely distributed in nature. They derive from dopaquinone, which is formed from L-tyrosine in a reaction catalyzed by tyrosinase in the pathway called melanogenesis. Melanins are responsible for skin and hair color in mammals. They also absorb ultraviolet radiation, protecting the skin from damage. However, excess of pigment accumulated in the skin leads to numerous disorders, e.g., freckles, melasma, age spots, or malignant melanoma $[3,4]$.

Tyrosinase is also responsible for the formation of dark pigment (enzymatic browning) in plant-derived foods. This process affects the shelf life of fresh products, decreasing their sensory properties [5].

There are several tyrosinase inhibitors of both natural and synthetic origin described in the literature [6-8]. Unfortunately, most of them are toxic or unstable; thus, they cannot be used orally or applied on the skin. Hydroquinone and kojic acid, known components of antipigmentation cosmetics, have been reported to be unsafe in concentrations required for a skin-lightening effect $[9,10]$. Therefore, there is a need ti search for and characterize new, safe, and effective tyrosinase inhibitors. 
Thiosemicarbazones are an interesting group of compounds. They are known for their numerous pharmacological and biological properties as effective antimicrobial [11], antimalarial [12], and anticancer [13] agents.

Tyrosinase possesses two copper ions in its active site, which makes it a potential target for thiosemicarbazones that might chelate ions via the thiourea moiety [14]. Indeed, thiosemicarbazones have gained interest as tyrosinase inhibitors, providing a half maximal inhibitory concentration $\left(\mathrm{IC}_{50}\right)$ on a micromolar level [15-23].

In our previous papers $[20,21]$, we reported that acetophenone thiosemicarbazones are more potent tyrosinase inhibitors than their benzaldehyde analogues. Halogenated acetophenone thiosemicarbazones revealed very good inhibitory properties, and some of them showed quite low toxicity toward the B16F10 cell line [21].

In the present work, we discuss the inhibitory effect of a series of monosubstituted $\left(-\mathrm{OH},-\mathrm{NH}_{2},-\mathrm{OCH}_{3},-\mathrm{NO}_{2}\right)$ acetophenone thiosemicarbazones on the diphenolase activity of tyrosinase. Twelve compounds were synthesized. The kinetics of the interaction between the inhibitors and tyrosinase, the effectiveness of the studied compounds in the inhibition of melanin production by murine melanoma B16F10 cells, and their cytotoxic activity toward B16F10 cells were investigated. The nature of tyrosinase-inhibitor interactions was explained on the basis of molecular docking of the structures to the active site of the enzyme.

\section{Results}

\subsection{Chemistry}

The chemical structures of all investigated compounds are shown in the Figure 1.<smiles>[R]c1cccc(/C(C)=N/NC(N)=S)c1</smiles>
TSC 1: $\quad \mathrm{R}=2-\mathrm{OMe}$
TSC 2: $\quad \mathrm{R}=3-\mathrm{OMe}$
TSC 3: $\quad \mathrm{R}=4-\mathrm{OMe}$
TSC 4: $\mathrm{R}=2-\mathrm{NH}_{2}$
TSC 5: $\quad \mathrm{R}=3-\mathrm{NH}_{2}$
TSC 6: $\mathrm{R}=4-\mathrm{NH}_{2}$
TSC 7: $\mathrm{R}=2-\mathrm{OH}$
TSC 8: $\quad \mathrm{R}=3-\mathrm{OH}$
TSC 9: $\quad \mathrm{R}=4-\mathrm{OH}$
TSC 10: $\mathrm{R}=2-\mathrm{NO}_{2}$
TSC 11: $\mathrm{R}=3-\mathrm{NO}_{2}$
TSC 12: $\mathrm{R}=4-\mathrm{NO}_{2}$

Figure 1. Chemical structures of tested thiosemicarbazone derivatives (TSCs).

The thiosemicarbazones TSCs 1-12 were prepared via the reaction of the appropriate substituted acetophenone with thiosemicarbazide in the presence of $p$-toluenesulfonic acid (Scheme 1) using a previously reported procedure [20,21].

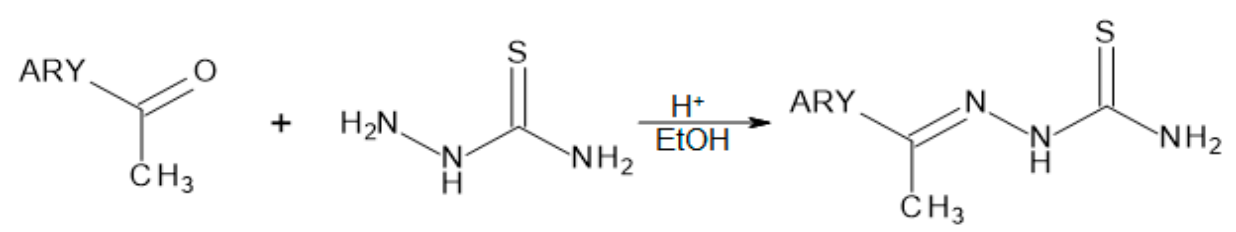

Scheme 1. Reaction scheme according to ${ }^{1} \mathrm{H}-\mathrm{NMR}$ spectroscopy and compared with literature data; in the case of the new TSCs, ${ }^{13} \mathrm{C}-\mathrm{NMR}$ and HRMS were also performed (Figures S1-S40, Supplementary Materials).

Most of the synthesized TSCs were obtained as single $E$-isomers, with the exception of the ortho-methoxy (TSC 1), ortho-amino (TSC 4), and ortho-hydroxy (TSC 7) derivatives which were obtained as a mixture of $E$ - and Z-isomers in the molar ratio 80:20, 90:10, and $92: 8$, respectively. The configuration of the obtained TSCs was distinguished on the basis of the analysis of the ${ }^{1} \mathrm{H}-\mathrm{NMR}$ spectra [24-26]. 
The signal of the $\mathrm{N}^{2} \mathrm{H}$ proton $(\mathrm{C}=\mathrm{N}-\mathrm{NH}-$ ) of the $E$-isomer of thiosemicarbazones of the aryl alkyl ketones appears in the range of $~ 10.2-10.6$ ppm $[15,27,28]$.

The chemical shift value of the $\mathrm{N}^{2} \mathrm{H}$ signal of the major isomer of thiosemicarbazones TSCs 1, 4, and 7 (Figure 2) indicates an E-configuration, which suggests that the minor isomer corresponds to the $Z$-isomer. Additionally, the geometry of the $\mathrm{C}=\mathrm{N}$ double bond of the main isomers of the mentioned TSCs was confirmed by two-dimensional (2D) NMR NOESY spectroscopy. In all three cases, a strong NOE interaction of the appropriate $\mathrm{N}^{2} \mathrm{H}$ signals with the protons of methyl group was observed, which allowed assigning the main isomers to $E$-isomers.<smiles>[X]c1ccccc1/C(C)=N/NC(N)=S</smiles><smiles>[X]c1ccccc1/C(C)=N\NC(N)=S</smiles>

E-isomer Z-isomer

$\mathrm{X}=\mathrm{OCH}_{3}\left(\right.$ TSC 1), $\mathrm{NH}_{2}$ (TSC 4), $\mathrm{OH}$ (TSC 7)

Figure 2. E- and Z-isomers of ortho-substituted thiosemicarbazones (TSC 1, 4, and 7).

\subsection{Effect of TSCs 1-12 on the Activity of Mushroom Tyrosinase}

The effect of tested TSCs 1-12 on the diphenolase activity of the enzyme was shown as the $\mathrm{IC}_{50}$. In order to determine the $\mathrm{IC}_{50}$, dose-response analysis for all investigated compounds was performed. The plots representing the relationship between relative activity (percent of inhibition) of the enzyme and the inhibitor concentration (logarithmtransformed for a better fit to a sigmoidal shape).

Dose-response curves for TSCs 1-12 are shown in Figure 3. Benzaldehyde TSC, acetophenone TSC, and kojic acid were used as positive controls in this research study. Benzaldehyde TSC and acetophenone TSC were reported as potent tyrosinase inhibitors in our previous papers $[20,21]$. Kojic acid is the most well known and studied tyrosinase inhibitor. It is often used as a reference compound when new tyrosinase inhibitors are tested $[29,30]$.

All tested compounds showed a dose-dependent manner of inhibition. Dose-response curves allowed determining the $\mathrm{IC}_{50}$ values, which are collected in Table 1 . All thiosemicarbazones inhibited the diphenolase activity of tyrosinase on a micromolar level of $\mathrm{IC}_{50}$, mostly ranging from 0.3 to almost $15 \mu \mathrm{M}$. Only TSC 10 showed an $\mathrm{IC}_{50}$ over $150 \mu \mathrm{M}$.

The $\mathrm{IC}_{50}$ parameter is very convenient, and it is the most often used to show the potency of inhibitors. However, depending on the kinetics of the enzyme-inhibitor interaction, it may depend on the substrate concentration; thus, this parameter is comparable across papers only when the test is taken in the same circumstances [31]. To avoid this drawback, the ratio of the $\mathrm{IC}_{50}$ of the investigated inhibitors to the reference compound can be calculated. As kojic acid is the most popular reference compound, the ratio of $\mathrm{IC}_{50}$ of kojic acid to the $\mathrm{IC}_{50}$ of the tested inhibitors was additionally calculated.

All tested TSCs revealed better inhibitory properties than kojic acid (except for TSC 10). Compounds 5-9 gave better results than acetophenone thiosemicarbazones (unsubstituted analogue of tested compounds).

TSCs $5,6,8$, and 9 achieved $\mathrm{IC}_{50}$ values lower than $1 \mu \mathrm{M}$ and can be considered as some of the most potent tyrosinase inhibitors described in the literature. They are 20-fold stronger inhibitors than kojic acid. TSC 6 achieving an $\mathrm{IC}_{50}$ of $0.34 \mu \mathrm{M}$ was the most potent one among all those studied in this research. 

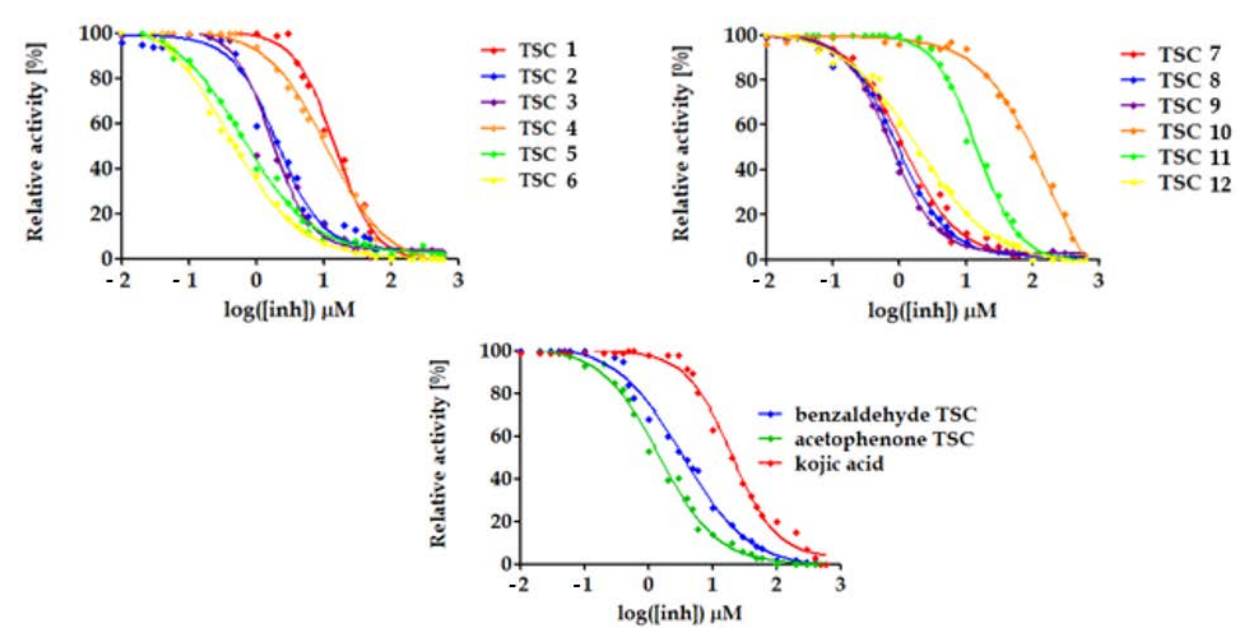

Figure 3. Dose-response curves for determination of half maximal inhibitory concentration $\left(\mathrm{IC}_{50}\right)$ for TSC s 1-12 and control compounds (benzaldehyde TSC, acetophenone TSC, and kojic acid) toward mushroom tyrosinase. The concentration of L-3,4-dihydroxyphenylalanine (L-DOPA) was $1 \mathrm{mM}$ in all the cases. Inhibitor concentration was in the range of 0.01 to $600 \mu \mathrm{M}$.

Table 1. $\mathrm{IC}_{50}$ values of the studied compounds on the diphenolase activity of mushroom tyrosinase.

\begin{tabular}{|c|c|c|c|}
\hline Compound & $\mathrm{IC}_{50}{ }^{1}(\mu \mathrm{M})$ & $\begin{array}{c}95 \% \mathrm{CI}^{2} \mathrm{IC}_{50}(\mu \mathrm{M}) \\
(n=3)\end{array}$ & $\begin{array}{l}\text { Ratio of } \mathrm{IC}_{50} \text { of Kojic } \\
\text { Acid to } \mathrm{IC}_{50} \text { of TSC }\end{array}$ \\
\hline TSC 1 & 12.2 & $10.3-14.8$ & 1.6 \\
\hline TSC 2 & 1.9 & $1.7-2.5$ & 10.5 \\
\hline TSC 3 & 1.8 & $1.3-2.1$ & 11.1 \\
\hline TSC 4 & 11.3 & $9.9-12.7$ & 1.8 \\
\hline TSC 5 & 0.65 & $0.5-0.7$ & 30.6 \\
\hline TSC 6 & 0.34 & $0.3-0.4$ & 58.5 \\
\hline TSC 7 & 1.2 & $1.0-1.2$ & 16.5 \\
\hline TSC 8 & 0.95 & $0.8-1.0$ & 20.9 \\
\hline TSC 9 & 0.80 & $0.7-0.9$ & 24.9 \\
\hline TSC 10 & 154,5 & $106.4-224.3$ & 0.1 \\
\hline TSC 11 & 14.2 & $12.91-15.79$ & 1.4 \\
\hline TSC 12 & 1.6 & $1.622-2.115$ & 12.4 \\
\hline Benzaldehyde TSC & 3.4 & $2.9-4.0$ & 5.6 \\
\hline Acetophenone TSC & 1.5 & $1.3-1.7$ & 13.2 \\
\hline Kojic acid & 19.9 & $17.2-23.9$ & 1.0 \\
\hline
\end{tabular}

${ }^{1}$ Inhibitor concentration required for $50 \%$ inhibition; ${ }^{2}$ confidence interval.

\subsection{Kinetic Studies}

The kinetics of the interaction between TSCs 1-12 and mushroom tyrosinase were determined. Kojic acid was used as a positive control. The inhibition type, mechanism, and inhibitory constants $\left(\mathrm{K}_{\mathrm{i}}\right.$ and $\left.\mathrm{K}_{\mathrm{is}}\right)$ were determined using graphical methods as described in our previous papers [20,21] and by Copeland [31]. The results are shown in Table 2.

The inhibition type was determined through creation of the Lineweaver-Burk plot (double reciprocal plot), which enables easier analysis of the Michaelis-Menten plot. Compounds 3, 6, 9, and 11 inhibited tyrosinase competitively, i.e., they competed with the tyrosinase substrates for the enzyme active site. TSCs 1, 2, 4, 5, 7, 8, 10, and 11 were mixedtype inhibitors, with an affinity for both the free enzyme and the enzyme-substrate complex. In all the cases of mixed inhibitors, $\mathrm{K}_{\mathrm{i}}$ values were lower than $\mathrm{K}_{\mathrm{is}}$, which means that the inhibitor affinity for the free enzyme was higher than that for the enzyme-substrate complex. 
Table 2. Inhibition type, mechanism, and the inhibition constant values of the examined compounds on the diphenolase activity of mushroom tyrosinase.

\begin{tabular}{|c|c|c|c|c|}
\hline Compound & $\begin{array}{l}\text { Inhibition } \\
\text { Mechanism }\end{array}$ & $\begin{array}{l}\text { Inhibition } \\
\text { Type }\end{array}$ & $\mathrm{K}_{\mathrm{i}}^{1} \pm \underset{(n=3)}{\operatorname{Standard~Error}(\mu \mathrm{M})}$ & $\mathrm{K}_{\mathrm{is}}{ }^{2} \pm \underset{(n=3)}{\operatorname{Standard} \text { Error }(\mu \mathrm{M})}$ \\
\hline TSC 1 & reversible & mixed & $5.0 \pm 1.4$ & $27.5 \pm 3.5$ \\
\hline TSC 2 & reversible & mixed & $1.0 \pm 0.1$ & $9.7 \pm 3.1$ \\
\hline TSC 3 & reversible & competitive & $0.6 \pm 0.01$ & - \\
\hline TSC 4 & reversible & mixed & $8.0 \pm 0.9$ & $30.4 \pm 0.5$ \\
\hline TSC 5 & reversible & mixed & $0.6 \pm 0.1$ & $3.05 \pm 1.1$ \\
\hline TSC 6 & reversible & competitive & $0.2 \pm 0.06$ & $3.5 \pm 0.8$ \\
\hline TSC 7 & reversible & mixed & $0.7 \pm 0.1$ & $5.3 \pm 2.1$ \\
\hline TSC 8 & reversible & mixed & $0.6 \pm 0.08$ & $5.4 \pm 0.1$ \\
\hline TSC 9 & reversible & competitive & $0.6 \pm 0.06$ & - \\
\hline TSC 10 & reversible & mixed & $8.6 \pm 0.5$ & $43.3 \pm 3.0$ \\
\hline TSC 11 & reversible & competitive & $0.4 \pm 0.02$ & - \\
\hline TSC 12 & reversible & mixed & $5.0 \pm 1.4$ & $27.5 \pm 3.5$ \\
\hline Kojic acid & reversible & mixed & $26 \pm 1$ & $72 \pm 3$ \\
\hline
\end{tabular}

${ }^{1}$ Inhibition constant for enzyme-inhibitor complex; ${ }^{2}$ inhibition constant for substrate-enzyme-inhibitor complex.

Inhibition constants $\mathrm{K}_{\mathrm{i}}$ were determined from the secondary plots of $k_{\mathrm{m}}$ (Michaelis constant) versus the inhibitor concentration for competitive inhibition and by the secondary plots of the slope of the lines from the Lineweaver-Burk plot as a function of the inhibitor concentration for mixed-type inhibition. Inhibition constant $\mathrm{K}_{\mathrm{is}}$ was determined from the secondary plots of $1 / \mathrm{V}_{\max }$ as a function of the inhibitor concentration for mixed-type inhibition. All investigated compounds achieved a lower $\mathrm{K}_{\mathrm{i}}$ value than kojic acid. TSCs 3, 5-9, and 11 revealed a $K_{i}$ lower than $1 \mu \mathrm{M}$. It is worth mentioning that para-substituted compounds showed a shared inhibition type. They were all competitive inhibitors, whereas meta- and ortho-substituted compounds were mixed inhibitors.

Results for the inhibitor affinity for the enzyme expressed in terms of $\mathrm{IC}_{50}$ and $\mathrm{K}_{\mathrm{i}}$ were mostly consistent. Compound 6 showed the lowest values for both these parameters. An exemplary set of plots for the determination of kinetic parameters is shown in Figure 4.
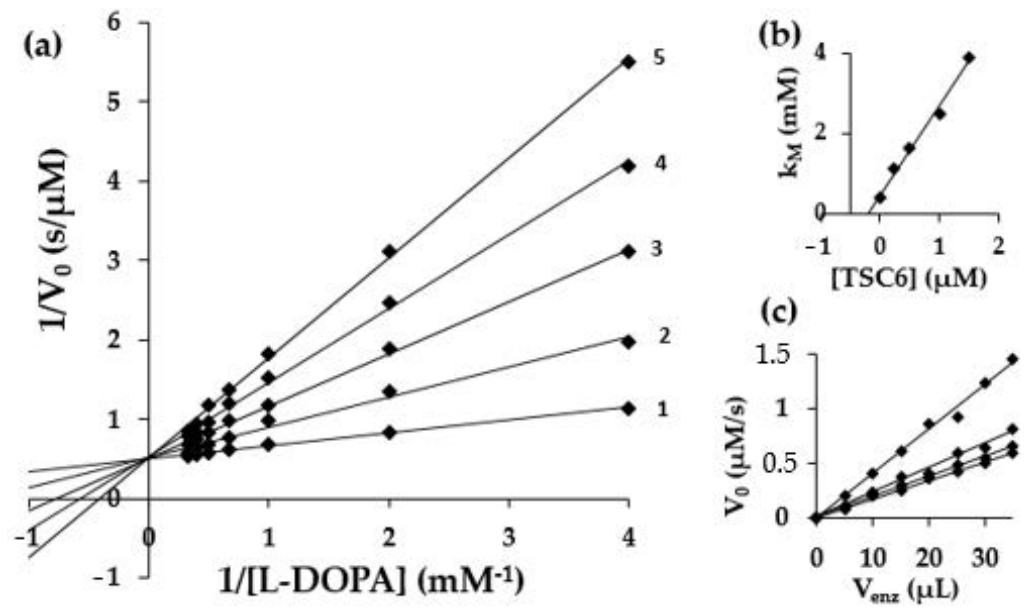

Figure 4. Lineweaver-Burk plots for inhibition of TSC 6 (a) on mushroom tyrosinase with L-DOPA as substrate. The concentrations of TSC 6 for curves $1-5$ were $0.0,0.1,0.2,0.3$, and $0.4 \mu \mathrm{M}$, respectively. (b) Secondary plot of $k_{m}$ versus inhibitor concentrations for determination of $\mathrm{K}_{\mathrm{i}}$ for competitive inhibition. (c) Plot to determine the inhibitory mechanism.

The inhibition mechanism for the investigated compounds was also tested. All studied thiosemicarbazones revealed a reversible manner of inhibition. As shown in Figure $4 c$, the plot representing the remaining tyrosinase activity versus the enzyme amount at different inhibitor concentrations for TSC 6 gave a family of straight lines which all passed through the origin of the coordinate system. The presence of the inhibitor reduced the enzyme activity for the same amount of the enzyme. 


\subsection{Molecular Docking}

Molecular docking is a helpful tool for an explanation of the interactions between investigated thiosemicarbazones and the enzyme. All TSCs were docked to the active site of mushroom tyrosinase (Protein Data Bank (PDB): 2Y9X) [32]. As a result of the docking process, for each inhibitor, three possible orientations of the docked molecules were obtained. The GoldScore fitness function [33] evaluated the probability of the orientation of the TSCs in the active site. The docked molecules obtaining the highest GoldScore (Table S1, Supplementary Materials) were chosen for the visualization of their orientation in the active site.

All molecules are shown in one figure along with the reference ligand (tropolone, the native ligand from the crystal structure of the protein used in the molecular modeling). Indeed, all 12 inhibitors fell into one cluster as along with the native ligand, as clearly visible in Figure 5.

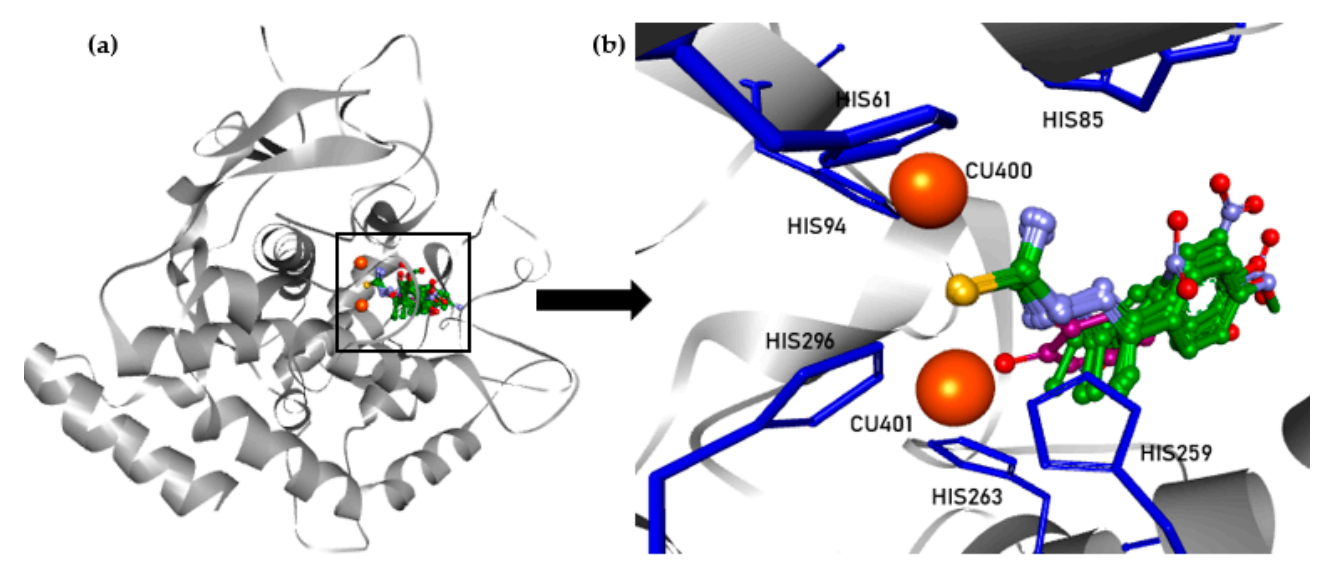

Figure 5. Orientation of TSCs 1-12 and tropolone in chain A of tyrosinase (a) and the active site of tyrosinase (b). Copper ions are represented as orange spheres; histidine residues are represented as blue sticks; inhibitors are represented by balls and sticks (green—carbon of TSCs; purple—carbon of tropolone, yellow—sulfur; light blue—nitrogen; red—oxygen, hydrogens are not presented).

In all cases, the adjustment of TSCs 1-12 in the active site of the enzyme showed the same manner. Inhibitors penetrated the active pocket with the thiourea moiety. For all inhibitors, the sulfur atom of thiourea was located between the two catalytic copper ions of the active site.

As all inhibitors were oriented in the same mode in the active site, there were similar types of interactions between them and residues of the enzyme (Figure 6).

All compounds interacted with copper ions ( $\mathrm{Cu} 400$ and $\mathrm{Cu} 401)$ in the active site.

For most of the investigated compounds, there was no interaction with the group located in the aromatic ring of the inhibitor. Hydroxyl and amino groups did not interact with the active site of the enzyme. Only TSCs 2, 10, and 11 showed an interaction with one of the hydrogens of the imidazole ring of His 244 via a hydrogen bond with the oxygen of the methoxy (TSC 2) or nitro group (TSCs 10 and 11) of the inhibitor. Interestingly, TSCs with a para-substituted aromatic ring did not reveal any interaction with the enzyme, in any case. 
TSC 1

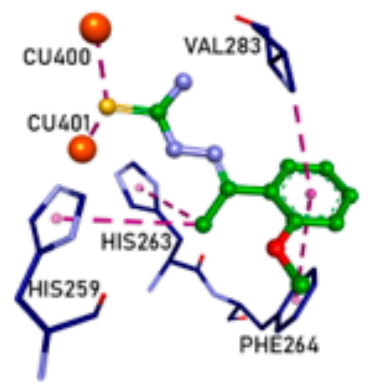

TSC 4

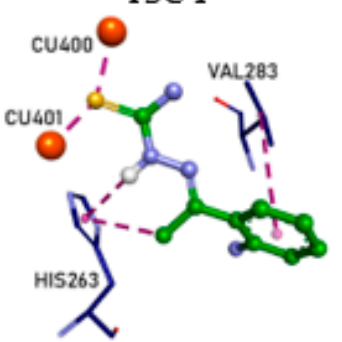

TSC 7

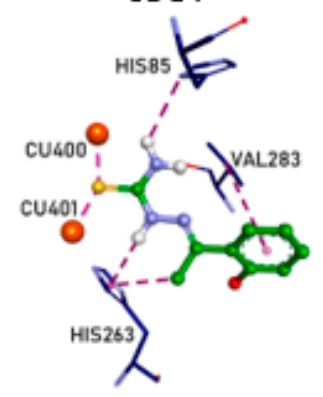

TSC 10

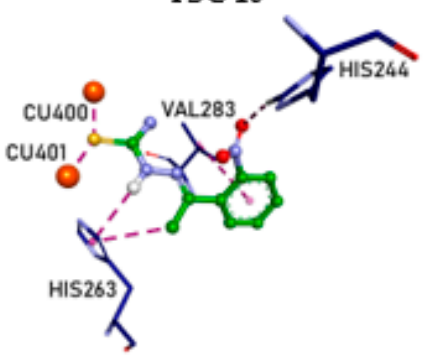

TSC 2

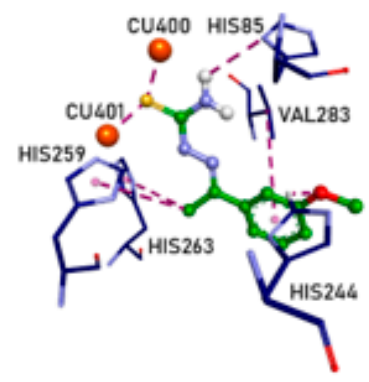

TSC 5

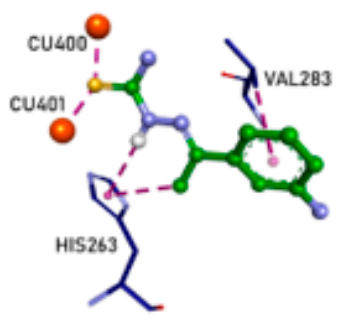

TSC 8

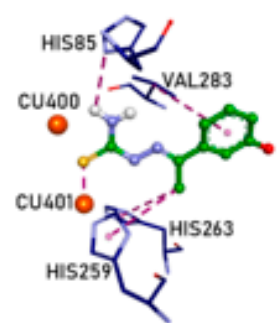

TSC 11

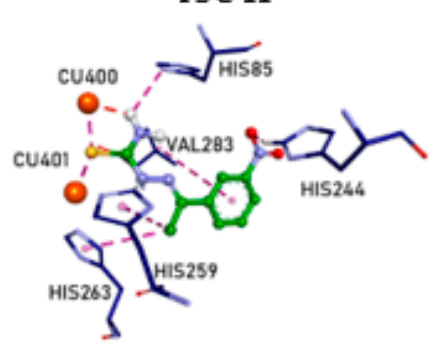

TSC 3

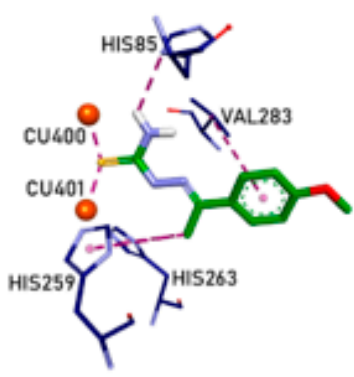

TSC 6

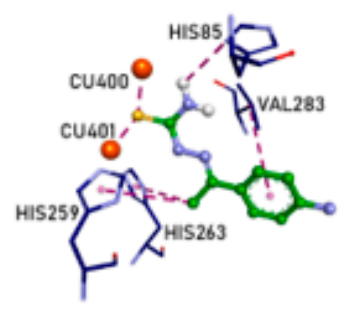

TSC 9

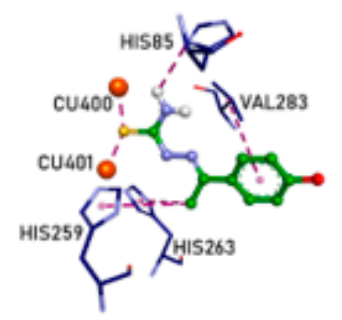

TSC 12

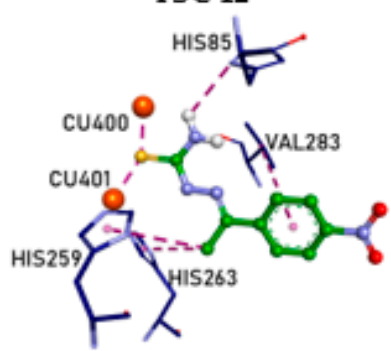

Figure 6. Interactions of TSCs 1-12 in the active site of tyrosinase visualized in BIOVIA Discovery StudioVisualizer [34]. Copper ions are represented as orange spheres; amino-acid residues are represented as sticks; inhibitors are represented by balls and sticks (green-carbon of TSCs; dark blue — carbon of amino acids, yellow—sulfur; light blue—nitrogen; red—oxygen; hydrogens are not presented if they did not participate in the interactions; purple lines-interactions).

TSCs 2, 3, 6-9, 11, and 12 were stabilized by a hydrogen bond formed between one of the hydrogens of the terminal amino group in the thiosemicarbazide moiety and the nitrogen in the imidazole ring of His85. TSCs 4, 5, 7, and 10 formed another hydrogen bond between the hydrogen of the hydrazine group and the imidazole ring ( $\pi$ donor) of His 263 .

All structures were additionally stabilized by multiple hydrophobic interactions: $\pi$ alkyl interactions of the $\mathrm{CH}_{3}$ group of the inhibitor with the imidazole of His259 and His263, as well as $\pi$-alkyl or $\pi$-sigma interactions between the aromatic ring of the inhibitors and Val283.

A detailed description of all interactions between TSCs 1-12 and the active site of tyrosinase, along with the length of these interactions, can be found in the Supplementary Materials (Section 1). 


\subsection{Effectiveness of TSCs in Melanogenesis Inhibition}

In order to investigate the inhibitory effect of the studied TSCs 1-12 on melanogenesis, B16F10 murine melanoma cells were stimulated with $\alpha$-melanocyte-stimulating hormone $(\alpha-\mathrm{MSH})$. In the presence of $\alpha-\mathrm{MSH}$, the cells were treated with the inhibitors after 24 $\mathrm{h}$. Then, the cells were incubated with TSCs at various concentrations $(1-100 \mu \mathrm{M})$ for $48 \mathrm{~h}$. Kojic acid was used as a positive control, and dimethyl sulfoxide (DMSO) was used as a solvent control. Melanin content was measured spectrophotometrically at 405 $\mathrm{nm}$. B16F10 cell viability was also estimated in the presence of the tested inhibitors, benzaldehyde thiosemicarbazone, kojic acid, and DMSO using the 3-(4,5-dimethylthiazol2-yl)-2,5-diphenyltetrazolium bromide (MTT) colorimetric assay.

The results of dose-response measurements $\left(\mathrm{IC}_{50}\right)$, along with confidence intervals, for the inhibition of melanin production and cell proliferation are shown in Table 3.

Table 3. Effectiveness of TSCs in inhibition of melanin production and B16F10 cell proliferation.

\begin{tabular}{|c|c|c|c|c|}
\hline \multirow[t]{2}{*}{ Compound } & \multirow{2}{*}{$\begin{array}{c}\begin{array}{c}\text { Inhibition of } \\
\text { Melanin Production }\end{array} \\
\mathrm{IC}_{50}{ }^{1}(\mu \mathrm{M})\end{array}$} & \multirow{2}{*}{$95 \% \mathrm{CI}^{2} \mathrm{IC}_{50}(\mu \mathrm{M})$} & $\begin{array}{l}\text { Inhibition of Cell } \\
\text { Proliferation }\end{array}$ & \multirow{2}{*}{$95 \% \mathrm{CI}^{2} \mathrm{IC}_{50}(\mu \mathrm{M})$} \\
\hline & & & $\mathrm{IC}_{50}{ }^{1}(\mu \mathrm{M})$ & \\
\hline TSC 1 & 39.2 & $36.57-42.03$ & 45.2 & $36.43-56.19$ \\
\hline TSC 2 & 13.5 & $12.45-14.68$ & 22.4 & $17.15-29.35$ \\
\hline TSC 3 & 13.1 & $11.68-14.65$ & 20.3 & $15.03-27.35$ \\
\hline TSC 4 & 207.8 & $135.2-319.6$ & $3113.4^{3}$ & 499.3-19414 \\
\hline TSC 5 & 88.9 & $81.41-97.12$ & 149.6 & $124.8-179.4$ \\
\hline TSC 6 & 139.4 & $126.3-153.9$ & 154.9 & $141.9-169.0$ \\
\hline TSC 7 & 21.7 & $18.50-25.49$ & 37.3 & $31.31-44.38$ \\
\hline TSC 8 & 69.5 & $60.05-80.48$ & 103.2 & $87.83-121.3$ \\
\hline TSC 9 & 25.2 & $19.39-32.75$ & 115.3 & $99.15-134.1$ \\
\hline TSC 10 & 77.8 & $74.16-81.57$ & 93.2 & $83.85-103.6$ \\
\hline TSC 11 & 44.0 & $38.48-50.43$ & 44.8 & $40.04-50.22$ \\
\hline TSC 12 & $1160.3^{4}$ & $219.7-6129$ & 136.6 & $109.7-170.0$ \\
\hline Kojic acid & 114.1 & $105.9-123.0$ & 152.7 & $138.4-168.6$ \\
\hline DMSO & 8019.8 & $140.5-457,651$ & 166.4 & $153.4-180.6$ \\
\hline
\end{tabular}

${ }^{1}$ Inhibitor concentration required for $50 \%$ inhibition; ${ }^{2}$ confidence interval; ${ }^{3}$ change in color of the solution during 3-(4,5-dimethylthiazol-2-yl)-2,5-diphenyltetrazolium bromide (MTT) assay affected the $\mathrm{IC}_{50}$ value; $^{4}$ yellow color of the solution affected the spectroscopic measurement at $405 \mathrm{~nm}$. DMSO, dimethyl sulfoxide.

Melanin production in B16F10 cells was inhibited by all tested TSCs. All of the investigated compounds revealed an $\mathrm{IC}_{50}$ at the micromolar level. Because of problems with the colorimetric assays, compounds 4 and 12 were not taken into consideration for further analysis. Almost all inhibitors showed a strong potency of melanogenesis inhibition (low $\mathrm{IC}_{50}$ values in comparison with positive control-kojic acid, which achieved an $\mathrm{IC}_{50}$ of $114.1 \mu \mathrm{M})$. The exception was TSC 6 which achieved an $\mathrm{IC}_{50}$ of $139.4 \mu \mathrm{M}$ for the inhibition of melanin production.

These results were verified with the effect of tested inhibitors on the proliferation of B16F10 cells (see Table 3). Low melanin production might have been caused by high toxicity (low $\mathrm{IC}_{50}$ for inhibition of cell proliferation) of the inhibitors which, in turn, could have led to the inhibition of cell proliferation.

TSCs $2,3,7$, and 9 influenced the melanin production at the relatively low concentration rate ( $\mathrm{IC}_{50}$ below $\left.30 \mu \mathrm{M}\right)$; however, in the case of compounds 2 and 3, this might have been caused by the toxicity of the compounds toward the cells.

In order to visualize the potency of TSCs in inhibiting melanin production with regard to their toxicity, the bar graph representing the ratio of the $\mathrm{IC}_{50}$ for the inhibition of $\mathrm{B} 16 \mathrm{~F} 10$ cell proliferation to the $\mathrm{IC}_{50}$ for the inhibition of melanin production was created for TSCs and kojic acid (Figure 7). 


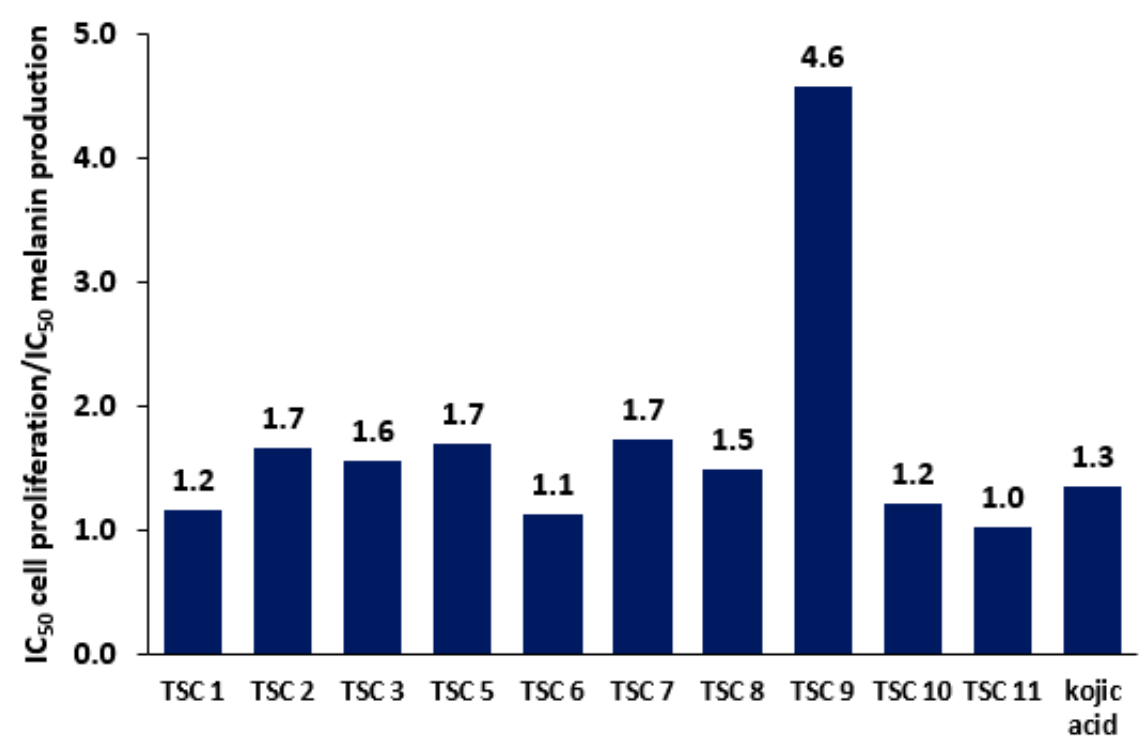

Figure 7. Ratio of $\mathrm{IC}_{50}$ for the inhibition of $\mathrm{B} 16 \mathrm{~F} 10$ cell proliferation to $\mathrm{IC}_{50}$ for the inhibition of melanin production.

A higher bar denotes a better ratio of melanogenesis inhibition to toxicity. For compounds $1-3,5-8,10$, and 11 , the value of this ratio was between 1 and 2 . The compound leading to the highest bar was compound 9, which means it can be considered as a potent nontoxic inhibitor of melanogenesis in B16F10 cells.

\section{Discussion}

In the frame of this study, 12 TSCs were synthesized and their inhibitory activity toward mushroom tyrosinase was examined. Moreover, the molecular docking of these compounds to the active site of the enzyme was performed, and their ability to inhibit melanogenesis and cell proliferation in B16F10 cells was tested.

Some general points regarding the structure-activity relationship of thiosemicarbazones can be concluded on the basis of the results of the dose-response analysis and obtained $\mathrm{IC}_{50}$ values.

According to the observed great impact of the methyl group, instead of hydrogen, on the biological activity of the thiosemicarbazones toward tyrosinase in our previous papers [20,21], it was decided to test a group of acetophenone thiosemicarbazone derivatives possessing methoxy, amino, hydroxyl, and nitro substituents on the phenyl ring at the ortho-, meta-, and para-positions. The structure-activity relationship is very similar to compounds substituted with halogen atoms $(\mathrm{Br}, \mathrm{Cl}, \mathrm{F})$ concerning the position of substitution on the phenyl ring [21]. In all cases, the ortho-position provided the highest $\mathrm{IC}_{50}$ values as compared to the meta- and para-substitutions. For compounds with amino (TSC 1), methoxy (TSC 4), and hydroxyl (TSC 7) groups, the values of $\mathrm{IC}_{50}$ were $11.3,12.2$, and $1.2 \mu \mathrm{M}$, respectively. A nitro group at the ortho-position (TSC 10) increased the $\mathrm{IC}_{50}$ to $154.5 \mu \mathrm{M}$. There were no significant differences in $\mathrm{IC}_{50}$ values between the meta- and paraposition for compounds possessing hydroxyl, amino, and methoxy groups. However, in all abovementioned cases, the para-substitution was slightly more beneficial. For compounds with a nitro group, the inhibitory activity visibly decreased from the para- to ortho-position. In the case of these compounds, the type of group substituted seemed to have a greater impact on the biological activity than in the case of halogen substituents [21]. The methoxy substituent provided $\mathrm{IC}_{50}$ values of 1.8 and $1.9 \mu \mathrm{M}$ for TSCs 3 (para) and 2 (meta), respectively. The hydroxyl and amino groups at the meta- and para-position achieved an $\mathrm{IC}_{50}$ below $1 \mu \mathrm{M}$, and TSC 6 (4-aminoacetophenone thiosemicarbazone) possessed the best inhibitory properties among all investigated thiosemicarbazones in this study, reaching the lowest $\mathrm{IC}_{50}$ value of $0.34 \mu \mathrm{M}$. 
In general, it is reported in the literature that thiosemicarbazones are reversible inhibitors of mushroom tyrosinase, revealing all types of inhibition (competitive, noncompetitive, uncompetitive, and mixed) depending on the substituents. This indicates that TSCs have an affinity for both the free enzyme and the substrate-enzyme complex. In the case of our studies, there was a certain relationship between the type of inhibition and the structure. The para-substituted acetophenone thiosemicarbazones were competitive inhibitors, whereas the meta- and ortho-substituted compounds showed a mixed type of inhibition. This is coherent with our results reported for halogenated acetophenone TSCs [21].

Molecular docking studies showed that the investigated TSCs penetrated the active site of tyrosinase via the thiourea moiety. All molecules fell into the same cluster; thus, their orientation in the active site did not explain the changes in the activity of particular TSCs. However, it is clear that the thiourea moiety is essential in the inhibition process, as in all cases for all compounds, the sulfur atom interacted with copper ions in the active site. Moreover, tropolone (native ligand of the crystal structure) occupied the same position as all TSCs but did not chelate any of the catalytic copper ions [32]. Hydrophobic interactions seem to substantially contribute to the inhibition process, which could have been predicted from the fact that tyrosinase's active site possesses multiple hydrophobic amino-acid residues [35]. Another important type of interaction stabilizing the structures in the active site was the hydrogen bond. Monosubstituted acetophenone thiosemicarbazone derivatives seemed to interact in a very similar way with the active site of the enzyme independently of the type of substituent on the aromatic ring. The results of the current research are similar to our results reported [21] for halogenated acetophenone thiosemicarbazone derivatives. These insights might be helpful in designing and developing novel tyrosinase inhibitors.

All investigated thiosemicarbazones inhibited melanogenesis in B16F10 cells at the micromolar level. Surprisingly, the substitution of the aromatic ring of the inhibitors with groups analyzed in this paper (methoxy, hydroxy, amino, and nitro) provided higher $\mathrm{IC}_{50}$ values for both the inhibition of melanin production and the inhibition of cell proliferation as compared with halogen substituents [21]. Moreover, the ratio of the $\mathrm{IC}_{50}$ for the inhibition of $\mathrm{B} 16 \mathrm{~F} 10$ cell proliferation to the $\mathrm{IC}_{50}$ for the inhibition of melanin production was much lower than for halogenated analogues. It seems that, despite a similar affinity for tyrosinase, the investigated compounds showed a lesser inhibitory effect on the whole melanogenesis process. Interestingly, TSC 6 , which showed the best inhibitory properties toward tyrosinase, turned out to be very weak inhibitor of melanogenesis.

Almost all studies related to the inhibition of tyrosinase were performed using mushroom tyrosinase. In fact, the enzyme from Agaricus bisporus is easily available in purified form, it is very active, and the enzymatic assay is convenient. Moreover, it is highly homologous with the mammalian enzyme, which makes it a common model for studies on melanogenesis in mammals [36-38]. Unfortunately, there are limitations to such an experimental approach. In spite of the similarities between human and mushroom tyrosinases, such as the conserved active site, there are also numerous structural differences which might influence the inhibition process. Human tyrosinase is a monomer undergoing glycosylation during its maturation, whereas the mushroom enzyme is a tetramer. The human enzyme is membrane-bound in contrast with the mushroom one which is located in the cytosol [29]. Some studies reported that the affinity of inhibitors for mammalian tyrosinase is lower than that for the mushroom one [39]. There is no research on thiosemicarbazones as human or mammalian tyrosinase inhibitors. Moreover, there is no crystal structure of human tyrosinase reported. Further investigations should also be made for the human enzyme to confirm the strong potency of thiosemicarbazones as tyrosinase inhibitors.

Results of our studies show that introducing simple groups (methoxy, hydroxy, amino, and nitro) to the thiosemicarbazone structure can improve its inhibitory properties toward tyrosinase, and this might be useful in the design of new skin-lightening agents or antibrowning compounds. 


\section{Materials and Methods \\ 4.1. Chemistry}

General information: thiosemicarbazide, $p$-toluenesulfonic acid monohydrate, and all used substituted acetophenones were purchased from Sigma-Aldrich (Taufkirchen, Germany), while $96 \%$ ethanol and methanol were obtained from a local supplier (Avantor Performance Materials Poland S.A.). High-resolution mass spectra were obtained on an LCT Premier XE Waters apparatus, in positive electrospray ionization (ESI+) mode. The spectra were recorded on $600 \mathrm{MHz}$ Bruker Avance and Jeol ECZ 400S spectrometers in DMSO- $\mathrm{d}_{6}$ as the solvent. Chemical shifts $(\delta)$ were reported in ppm relative to solvent signals (2.50 ppm and $39.52 \mathrm{ppm}$ in ${ }^{1} \mathrm{H}$ - and ${ }^{13} \mathrm{C}-\mathrm{NMR}$ spectra, respectively). The following abbreviations for multiplicity were used: $\mathrm{s}=$ singlet, $\mathrm{d}=$ doublet, $\mathrm{t}=$ triplet, $\mathrm{q}=$ quartet, quint $=$ quintet, sext $=$ sextet, hept $=$ heptet, $\mathrm{m}=$ multiplet, and $\mathrm{br}=$ broad .

General Procedure for the Synthesis of TSCs 1-12

The mixture of appropriate substituted acetophenone $(0.016 \mathrm{~mol})$, thiosemicarbazide $(1.8 \mathrm{~g}, 0.02 \mathrm{~mol})$, and $p$-toluenesulfonic acid monohydrate $(3.0 \mathrm{~g}, 0.016 \mathrm{~mol})$ in $96 \%$ ethanol $(50 \mathrm{~mL})$ was refluxed for about $8 \mathrm{~h}$, cooled to room temperature, and added in few portions to vigorously stirred $10 \%$ sodium bicarbonate solution $(250 \mathrm{~mL})$. Stirring was continued for about $30 \mathrm{~min}$, and the resulting solid was filtered, washed intensively with water $(2 \times 50 \mathrm{~mL}, 10 \times 20 \mathrm{~mL})$, and dried in air giving crude TSCs. Analytical samples were obtained by crystallization from $96 \%$ ethanol (TSCs $2-4$, TSC 7 and TSC 9) or methanol (TSC 1 , TSCs 5-6, TSC 8, and TSCs 10-12).

Mixture of (E)- and (Z)-2'-methoxyacetophenone thiosemicarbazone (in ca. 80:20 molar ratio, according to ${ }^{1} \mathrm{H}-\mathrm{NMR}$ ) (TSC 1): yield $80 \% ;{ }^{1} \mathrm{H}-\mathrm{NMR}\left(600 \mathrm{MHz}, \mathrm{DMSO}-\mathrm{d}_{6}\right) \delta$ : 2.20 (s, $\mathrm{CH}_{3}, \mathrm{Z}$-isomer) and 2.23 (s, $\mathrm{CH}_{3}, E$-isomer) (total integration $\left.3 \mathrm{H}\right), 3.817\left(\mathrm{~s}, \mathrm{OCH}_{3}\right.$, E-isomer) and $3.82\left(\mathrm{~s}, \mathrm{OCH}_{3}, \mathrm{Z}\right.$-isomer) (total integration $\left.3 \mathrm{H}\right), 6.96(\mathrm{dt}, \mathrm{J}=0.6 \mathrm{~Hz}, \mathrm{~J}=7.2 \mathrm{~Hz}$, $\operatorname{ArH}, E$-isomer) and $7.11(\mathrm{dt}, \mathrm{J}=1.2 \mathrm{~Hz}, \mathrm{~J}=7.2 \mathrm{~Hz}, \operatorname{ArH}, \mathrm{Z}$-isomer) (total integration $1 \mathrm{H}$ ), $7.06(\mathrm{~d}, \mathrm{~J}=8.4 \mathrm{~Hz}, E$-isomer) and $7.21(\mathrm{~d}, \mathrm{~J}=7.8 \mathrm{~Hz}, \mathrm{Z}$-isomer) (total integration $1 \mathrm{H}), 7.23$ $(\mathrm{d}, \mathrm{J}=7.8 \mathrm{~Hz}, \mathrm{Z}$-isomer) and $7.42(\mathrm{dd}, \mathrm{J}=1.8 \mathrm{~Hz}, \mathrm{~J}=7.8 \mathrm{~Hz}, E$-isomer) (total integration $1 \mathrm{H}), 7.38(\mathrm{dt}, \mathrm{J}=1.8 \mathrm{~Hz}, \mathrm{~J}=8.4 \mathrm{~Hz}, \mathrm{ArH}, E$-isomer) and $7.50(\mathrm{dt}, \mathrm{J}=1.8 \mathrm{~Hz}, \mathrm{~J}=7.8 \mathrm{~Hz}$, $\mathrm{ArH}, \mathrm{Z}$-isomer) (total integration $1 \mathrm{H}), 7.64$ (bs, $\mathrm{NH}, \mathrm{E}$-isomer) and 7.89 (bs, $\mathrm{NH}, \mathrm{Z}$-isomer) (total integration $1 \mathrm{H}), 8.19$ (bs, $\mathrm{NH}$, -isomer) and 8.24 (bs, NH, Z-isomer) (total integration $1 \mathrm{H}), 8.36$ (bs, $\mathrm{NH}, \mathrm{Z}$-isomer) and 10.18 (s, NH, E-isomer) (total integration $1 \mathrm{H}) .{ }^{13} \mathrm{C}-\mathrm{NMR}$ $(100 \mathrm{MHz}$, DMSO-d 6 ) $\delta$ : major, E-isomer: $18.68,56.07,112.11,120.83,129.09,130.06,130.83$, 150.97, 157.77, 179.46; minor Z-isomer: 24.64, 56.28, 112.82, 121.82, 122.75, 128.50, 131.86, 148.84, 155.68, 179.46. HRMS (ESI +$): m / z$ calculated for $\mathrm{C}_{10} \mathrm{H}_{14} \mathrm{~N}_{3} \mathrm{OS}(\mathrm{M}+\mathrm{H})^{+} 224.0858$, found 224.0856 .

(E)-3'-Methoxyacetophenone thiosemicarbazone (TSC 2): yield 97\%; ${ }^{1} \mathrm{H}-\mathrm{NMR}(600 \mathrm{MHz}$, DMSO-d $\left.\mathrm{d}_{6}\right) \delta: 2.30\left(\mathrm{~s}, 3 \mathrm{H}, \mathrm{CH}_{3}\right), 3.81\left(\mathrm{~s}, 3 \mathrm{H}, \mathrm{CH}_{3} \mathrm{O}\right), 6.97(\mathrm{dd}, 1 \mathrm{H}, \mathrm{J}=3.0 \mathrm{~Hz}, \mathrm{~J}=8.4 \mathrm{~Hz}, \mathrm{ArH})$, $7.31(\mathrm{t}, 1 \mathrm{H}, \mathrm{J}=7.8 \mathrm{~Hz}, \operatorname{ArH}), 7.44-7.49(\mathrm{~m}, 2 \mathrm{H}, \mathrm{ArH}), 7.95(\mathrm{bs}, 1 \mathrm{H}, \mathrm{NH}), 8.29(\mathrm{bs}, 1 \mathrm{H}, \mathrm{NH})$, $10.20(\mathrm{~s}, 1 \mathrm{H}, \mathrm{NH})$. NMR data are in agreement with those reported in the literature [40,41].

(E)-4'-Methoxyacetophenone thiosemicarbazone (TSC 3): yield 91\%; ${ }^{1} \mathrm{H}-\mathrm{NMR}(600 \mathrm{MHz}$, DMSO-d $\left.\mathrm{d}_{6}\right) \delta: 2.28\left(\mathrm{~s}, 3 \mathrm{H}, \mathrm{CH}_{3}\right), 3.80\left(\mathrm{~s}, 3 \mathrm{H}, \mathrm{CH}_{3} \mathrm{O}\right), 6.93(\mathrm{~d}, 2 \mathrm{H}, \mathrm{J}=8.7 \mathrm{~Hz}, \mathrm{ArH}), 7.86-792$ $(\mathrm{d}+\mathrm{bs}, 3 \mathrm{H}, \mathrm{J}=7.8 \mathrm{~Hz}, \mathrm{ArH}+\mathrm{NH}), 8.22(\mathrm{bs}, 1 \mathrm{H}, \mathrm{NH}), 10.13(\mathrm{~s}, 1 \mathrm{H}, \mathrm{NH})$. NMR data are in agreement with those reported in the literature [27].

Mixture of (E)- and (Z)-2'-aminoacetophenone thiosemicarbazone (in ca. 90:10 molar ratio, according to $\left.{ }^{1} \mathrm{H}-\mathrm{NMR}\right)$ (TSC 4): yield $91 \%$; ${ }^{1} \mathrm{H}-\mathrm{NMR}\left(400 \mathrm{MHz}, \mathrm{DMSO}-\mathrm{d}_{6}\right) \delta: 2.18(\mathrm{~s}$, $\mathrm{CH}_{3}, \mathrm{Z}$-isomer) and 2.23 (s, $\mathrm{CH}_{3}, E$-isomer) (total integration $\left.3 \mathrm{H}\right), 5.16\left(\mathrm{~s}, \mathrm{NH}_{2}, \mathrm{Z}\right.$-isomer) and 6.00 (bs, $\mathrm{NH}_{2}, E$-isomer) (total integration $\left.2 \mathrm{H}\right), 6.50(\mathrm{t}, \mathrm{J}=8.0 \mathrm{~Hz}, \mathrm{ArH}, \mathrm{E}$-isomer) and $6.65(\mathrm{t}, \mathrm{J}=7.6 \mathrm{~Hz}, \mathrm{ArH}, \mathrm{Z}$-isomer) (total integration $1 \mathrm{H}), 6.67(\mathrm{~d}, \mathrm{~J}=8.0 \mathrm{~Hz}, E$-isomer) and $6.79(\mathrm{~d}, \mathrm{~J}=7.6 \mathrm{~Hz}, \mathrm{Z}$-isomer) (total integration $1 \mathrm{H}), 7.00(\mathrm{t}, \mathrm{J}=7.2 \mathrm{~Hz}, E$-isomer + overlapped signal Z-isomer) and $7.13(\mathrm{dt}, \mathrm{J}=1.6 \mathrm{~Hz}, \mathrm{~J}=8.4 \mathrm{~Hz}, \mathrm{Z}$-isomer) and $7.29(\mathrm{~d}$, $\mathrm{J}=8.0 \mathrm{~Hz}, E$-isomer) (total integration $2 \mathrm{H}), 7.43$ (bs, NH, E-isomer) and 7.77 (bs, $N H$, Z-isomer) (total integration 1H), 8.13 (bs, NH, E-isomer) and 8.26 (bs, NH, Z-isomer) (total 
integration $1 \mathrm{H}), 8.61$ (bs, NH, Z-isomer) and 10.06 (s, NH, E-isomer) (total integration 1H). ${ }^{13} \mathrm{C}-\mathrm{NMR}\left(100 \mathrm{MHz}, \mathrm{DMSO}-\mathrm{d}_{6}\right) \delta$ : major, E-isomer: 16.92 (bs), 115.89 (bs), 116.64 (bs), 120.34 (bs), 130.00 (bs), 147.60 (bs), 153.65 (bs), 179.03 (bs), (one aromatic CH carbon signal is missing, probably due to the broadening and overlaps); minor Z-isomer: $24.47,116.72$, $117.55,119.60,128.08,130.91,144.41,150.51,178.35$. HRMS (ESI+): $m / z$ calculated for $\mathrm{C}_{9} \mathrm{H}_{13} \mathrm{~N}_{4} \mathrm{~S}(\mathrm{M}+\mathrm{H})^{+}$209.0861, found 209.0858.

(E)-3'-Aminoacetophenone thiosemicarbazone (TSC 5): yield 97\%; ${ }^{1} \mathrm{H}-\mathrm{NMR}(600 \mathrm{MHz}$, $\left.\mathrm{DMSO}_{-} \mathrm{d}_{6}\right) \delta: 2.24\left(\mathrm{~s}, 3 \mathrm{H}, \mathrm{CH}_{3}\right), 5.06\left(\mathrm{bs}, 2 \mathrm{H}, \mathrm{NH}_{2}\right), 6.61(\mathrm{~m}, 1 \mathrm{H}, \mathrm{ArH}), 7.01-7.06(\mathrm{~m}, 2 \mathrm{H}$, $\mathrm{ArH}), 7.11$ (m, 1H, ArH), 7.69 (bs, 1H, NH), 8.31 (bs, 1H, NH), 10.20 (s, 1H, NH). NMR data are in agreement with those reported in the literature $[16,42,43]$.

(E)-4'-Aminoacetophenone thiosemicarbazone (TSC 6): yield 94\%; ${ }^{1} \mathrm{H}-\mathrm{NMR}(400 \mathrm{MHz}$, $\left.\mathrm{DMSO}_{-} \mathrm{d}_{6}\right) \delta: 2.13\left(\mathrm{~s}, 3 \mathrm{H}, \mathrm{CH}_{3}\right), 5.42\left(\mathrm{bs}, 2 \mathrm{H}, \mathrm{NH}_{2}\right), 6.48(\mathrm{~d}, 2 \mathrm{H}, \mathrm{J}=8.8 \mathrm{~Hz}, \mathrm{ArH}), 7.57$ (d, $2 \mathrm{H}, \mathrm{J}=8.8 \mathrm{~Hz}, \mathrm{ArH}), 7.68(\mathrm{bs}, 1 \mathrm{H}, \mathrm{NH}), 8.04(\mathrm{bs}, 1 \mathrm{H}, \mathrm{NH}), 9.92(\mathrm{~s}, 1 \mathrm{H}, \mathrm{NH})$. NMR data are in agreement with those reported in the literature $[16,43]$.

Mixture of (E)- and (Z)-2'-hydroxyacetophenone thiosemicarbazone (in 92:8 molar ratio, according to ${ }^{1} \mathrm{H}-\mathrm{NMR}$ ) (TSC 7): yield 74 \%; ${ }^{1} \mathrm{H}-\mathrm{NMR}\left(400 \mathrm{MHz}, \mathrm{DMSO}-\mathrm{d}_{6}\right) \delta: 2.17$ (s, $\mathrm{CH}_{3}, \mathrm{Z}$-isomer) and $2.27\left(\mathrm{~s}, \mathrm{CH}_{3}\right.$, E-isomer) (total integration $\left.3 \mathrm{H}\right), 6.81(\mathrm{t}, \mathrm{J}=8.4 \mathrm{~Hz}$, $\mathrm{ArH}, \mathrm{E}$-isomer) and $6.91(\mathrm{t}, \mathrm{J}=7.6 \mathrm{~Hz}, \mathrm{ArH}$, Z-isomer) (total integration $1 \mathrm{H}), 6.82(\mathrm{~d}$, $\mathrm{J}=8.8 \mathrm{~Hz}, E$-isomer) and $6.96(\mathrm{~d}, \mathrm{~J}=8.4 \mathrm{~Hz}, \mathrm{Z}$-isomer) (total integration $1 \mathrm{H}), 7.15(\mathrm{dd}$, $\mathrm{J}=1.6 \mathrm{~Hz}, \mathrm{~J}=7.6 \mathrm{~Hz}, \mathrm{Z}$-isomer) and $7.48(\mathrm{~d}, \mathrm{~J}=8.0 \mathrm{~Hz}$, E-isomer) (total integration $1 \mathrm{H})$, $7.20(\mathrm{dt}, \mathrm{J}=1.2 \mathrm{~Hz}, \mathrm{~J}=8.0 \mathrm{~Hz}$, E-isomer) and $7.28(\mathrm{dt}, \mathrm{J}=1.6 \mathrm{~Hz}, \mathrm{~J}=8.8 \mathrm{~Hz}$, Z-isomer) (total integration 1H), 7.55 (bs, NH, E-isomer), 7.81 (bs, NH, Z-isomer), 8.13 (bs, NH, Eisomer), 8.29 (bs, $\mathrm{NH}$, Z-isomer), 8.39 (bs, $\mathrm{NH}$, Z-isomer) and 10.58 (bs, $\mathrm{NH}, \mathrm{E}$-isomer) (total integration $3 \mathrm{H}$ ), 10.31 (bs, $\mathrm{OH}, \mathrm{Z}$-isomer) and 12.66 (bs, $\mathrm{OH}, \mathrm{E}$-isomer) (total integration $\sim 0.6 \mathrm{H}$ (due to strong broadening of the signal at $12.66 \mathrm{ppm}$, observed integration is lower than the theoretical)). ${ }^{13} \mathrm{C}-\mathrm{NMR}\left(100 \mathrm{MHz}, \mathrm{DMSO}-\mathrm{d}_{6}\right) \delta$ : major, E-isomer: 14.60 (bs), 117.44 (bs), 119.18 (bs), 129.06 (bs), 131.12 (bs), 152.68 (bs), 157.79 (bs), 181.04 (bs), (one aromatic $\mathrm{CH}$ carbon signal is missing, probably due to the broadening and overlaps); minor Z-isomer: 24.69, 116.88, 120.41, 121.35, 128.79, 131.63, 149.41, 153.65, 178.22. Note: on ${ }^{1} \mathrm{H}$ - and ${ }^{13} \mathrm{C}$-NMR spectra an peaks of residual crystallization solvent (ethanol) are present. HRMS (ESI+): $m / z$ calculated for $\mathrm{C}_{9} \mathrm{H}_{12} \mathrm{~N}_{3} \mathrm{OS}(\mathrm{M}+\mathrm{H})^{+} 210.0701$, found 210.0702; Thiosemicarbazone TSC 7 is described in the literature as a single isomer $[42,44]$.

(E)-3'-Hydroxyacetophenone thiosemicarbazone (TSC 8): yield 81\%; ${ }^{1} \mathrm{H}-\mathrm{NMR}(400 \mathrm{MHz}$, DMSO- $\left.\mathrm{d}_{6}\right)$ of the methanol solvate of TSC $8\left(\mathrm{TSC} 8 \bullet \mathrm{CH}_{3} \mathrm{OH}\right) \delta: 2.21\left(\mathrm{~s}, 3 \mathrm{H}, \mathrm{CH}_{3}\right), 2.47(\mathrm{~s}$, $\left.\sim 3 \mathrm{H}, \mathrm{CH}_{3} \mathrm{OH}\right), 4.08\left(\mathrm{bs}, \sim 1 \mathrm{H}, \mathrm{CH}_{3} \mathrm{OH}\right), 6.75(\mathrm{dd}, 1 \mathrm{H}, \mathrm{J}=2.0 \mathrm{~Hz}, \mathrm{~J}=8.0 \mathrm{~Hz}, \mathrm{ArH}), 7.13(\mathrm{t}, 1 \mathrm{H}$, $\mathrm{J}=7.6 \mathrm{~Hz}, \operatorname{ArH}), 7.20(\mathrm{t}, 1 \mathrm{H}, \mathrm{J}=2.0 \mathrm{~Hz}, \operatorname{ArH}), 7.29(\mathrm{~d}, 1 \mathrm{H}, \mathrm{J}=7.6 \mathrm{~Hz}, \operatorname{ArH}), 7.74(\mathrm{bs}, 1 \mathrm{H}$, $\mathrm{NH}), 8.23$ (bs, 1H, NH), $9.42(\mathrm{~s}, 1 \mathrm{H}, \mathrm{OH}), 10.17(\mathrm{~s}, 1 \mathrm{H}, \mathrm{NH}) ;{ }^{13} \mathrm{C}-\mathrm{NMR}\left(100 \mathrm{MHz}, \mathrm{DMSO}-\mathrm{d}_{6}\right)$ $\delta: 14.70,49.13\left(\mathrm{CH}_{3} \mathrm{OH}\right), 113.80,116.82,118.04,129.75,139.58,148.65,157.76,179.40$. HRMS (ESI+): $m / z$ calculated for $\mathrm{C}_{9} \mathrm{H}_{12} \mathrm{~N}_{3} \mathrm{OS}(\mathrm{M}+\mathrm{H})^{+} 210.0701$, found 210.0708; NMR data of the obtained methanol solvate are in good agreement with those reported for the free TSC 8 [42].

(E)-4'-Hydroxyacetophenone thiosemicarbazone (TSC 9): yield 93\%; ${ }^{1} \mathrm{H}-\mathrm{NMR}(400 \mathrm{MHz}$,

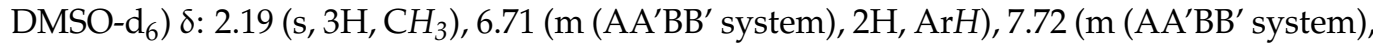
2H, ArH), 7.77 (bs, 1H, NH), 8.13 (bs, 1H, NH), 9.69 (s, 1H, OH), 10.03 (bs, 1H, NH). NMR data are in agreement with those reported in the literature $[42,45,46]$.

(E)-2'-Nitroacetophenone thiosemicarbazone (TSC 10): yield 31\%; ${ }^{1} \mathrm{H}-\mathrm{NMR}(400 \mathrm{MHz}$,

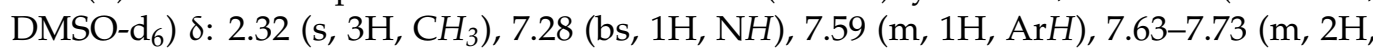
$\operatorname{ArH}), 7.92(\mathrm{~d}, 1 \mathrm{H}, \mathrm{J}=7.2 \mathrm{~Hz}, \mathrm{ArH}), 8.28$ (bs, 1H, NH), 10.36 (s, 1H, NH). NMR data are in agreement with those reported in the literature [46].

(E)-3'-Nitroacetophenone thiosemicarbazone (TSC 11): yield 97\%; ${ }^{1} \mathrm{H}-\mathrm{NMR}(400 \mathrm{MHz}$,

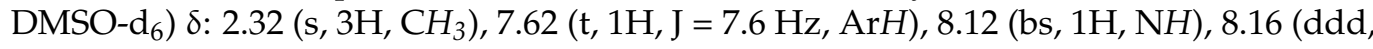
$1 \mathrm{H}, \mathrm{J}=0.8 \mathrm{~Hz}, \mathrm{~J}=2.4 \mathrm{~Hz}, \mathrm{~J}=8.4 \mathrm{~Hz}, \mathrm{ArH}), 8.36(\mathrm{bs}, 1 \mathrm{H}, \mathrm{NH}), 8.38(\mathrm{dd}, 1 \mathrm{H}, \mathrm{J}=1.6 \mathrm{~Hz}$, $\mathrm{J}=8.4 \mathrm{~Hz}, \mathrm{ArH}), 8.56(\mathrm{t}, 1 \mathrm{H}, \mathrm{J}=1.6 \mathrm{~Hz}, \mathrm{ArH}), 10.36(\mathrm{~s}, 1 \mathrm{H}, \mathrm{NH})$. NMR data are in agreement with those reported in the literature $[43,46]$. 
(E)-4'-Nitroacetophenone thiosemicarbazone (TSC 12): yield 94\%; ${ }^{1} \mathrm{H}-\mathrm{NMR}(400 \mathrm{MHz}$, DMSO-d $_{6}$ ) $\delta: 2.31\left(\mathrm{~s}, 3 \mathrm{H}, \mathrm{CH}_{3}\right), 8.11$ (bs, $\left.1 \mathrm{H}, \mathrm{NH}\right), 8.14$ (m (AA'BB' system), $\left.2 \mathrm{H}, \mathrm{ArH}\right)$, 8.18 (m (AA'BB' system), 2H, ArH), 8.43 (bs, $1 \mathrm{H}, \mathrm{NH}), 10.42(\mathrm{~s}, 1 \mathrm{H}, \mathrm{NH})$. NMR data are in agreement with those reported in the literature [47].

\subsection{Enzyme Preparation}

The enzyme was isolated from Agaricus bisporus, purchased from a local supplier in Wroclaw, and prepared as described in our previous papers [20,21], according to known procedures reported in the literature [48-50]. The full description of enzyme preparation is included in the Supplementary Materials (Section 2).

\subsection{Tyrosinase Enzymatic Assay}

The tyrosinase enzymatic assay was performed as described in our previous papers [20,21] using L-3,4-dihydroxyphenylalanine (L-DOPA) (Sigma-Aldrich, Taufkirchen, Germany) as a substrate. L-DOPA was dissolved in a $0.15 \mathrm{mM}$ phosphoric (V) acid solution to a concentration of $5 \mathrm{mM}$. All TSCs were dissolved in DMSO to a concentration of $50 \mathrm{mM}$ and then diluted in sodium phosphate buffer $(0.1 \mathrm{M}, \mathrm{pH}$ 6.8) to test concentrations (DMSO concentrations in final reaction mixtures did not exceeded $1 \%$ ).

The isolated tyrosinase solution $(0.5 \mathrm{mg} / \mathrm{mL}, 40,000 \mathrm{U} / \mathrm{mg})$ was diluted 10 times in sodium phosphate buffer $(0,1 \mathrm{M}, \mathrm{pH}$ 6.8). First, $10 \mu \mathrm{L}$ of the diluted enzyme solution was preincubated with TSC solutions ( $5 \mathrm{~min}$ at $25^{\circ} \mathrm{C}$ ). The optimal ionic strength and $\mathrm{pH}$ for tyrosinase activity were provided by $0.1 \mathrm{M}$ sodium phosphate buffer ( $\mathrm{pH}$ 6.8).

After the solution of L-DOPA was added, monitoring of the reaction was immediately started by measuring the change in absorbance of the color product (dopachrome) for $10 \min \left(\lambda=475 \mathrm{~nm}, 25^{\circ} \mathrm{C}\right)$ using Molecular Devices SpectraMax Plus 384 Microplate Reader. The control sample contained the same reagents as the test samples except for the substrate. Kojic acid (Sigma-Aldrich, Taufkirchen, Germany), a positive control, was treated the same way as the other inhibitors.

\subsection{Molecular Docking}

The structures of TSCs 1-12 were fully optimized in the Gaussian09 set of codes at the B3LYP / 6-311g $(\mathrm{d}, \mathrm{p})$ level of theory [51] with the polarizable continuum model (PCM) using water as the solvent [52]. The vibrational frequency analysis was performed to confirm that the obtained geometries were true minima on the potential energy surface (determined by the presence of no imaginary frequencies). The crystal structure of tyrosinase from Agaricus bisporus was obtained from the Research Collaboratory for Structural Bioinformatics (RCSB) Protein Data Bank (PDB: 2Y9X [32]). The ligand and the water molecules were removed from the structure of the enzyme. The structure was protonated, and charges were added to the protein using the $\mathrm{H}++$ server [53-56] according to a $\mathrm{pH}$ value of 6.8. Molecular docking in the defined active center of the protein was performed using the GOLD Algorithm [33]. The active site was selected as a sphere with the center in the location of the $\mathrm{Cu} 400$ atom and radius $10 \mathrm{~A}$. In the GOLD docking program [57], the default settings were used for all calculations: population size (100); selection pressure (1.1); number of operations $(10,000)$; number of islands (3); niche size (2); crossover frequency (100); mutation frequency (100); migration frequency (10) [58]. Analysis of inhibitor-enzyme interactions of the docked molecules was performed with Discovery Studio Visualizer 5 [34].

\subsection{Cell Proliferation Assay}

The B16F10 murine melanoma cell line was cultured in Dulbecco's modified Eagle medium (DMEM) (Biowest) supplemented with $100 \mathrm{U} / \mathrm{mL}$ streptomycin (Sigma-Aldrich, Taufkirchen, Germany), 100 U/mL penicillin (Sigma-Aldrich, Taufkirchen, Germany), and $10 \%$ fetal bovine serum (Sigma-Aldrich, Taufkirchen, Germany). Cells were maintained in $5 \% \mathrm{CO}_{2}$ at $37^{\circ} \mathrm{C}$. 
Cell viability was estimated using the MTT colorimetric assay as described in our previous papers $[20,21]$ and by Bellei et al. [59]. B16 cells were seeded into a 96-well plate $\left(4 \times 10^{3}\right.$ cells/well $)$ and incubated in the presence of investigated thiosemicarbazones in various concentrations $(1000,400,100,40,10,1$, and $0.1 \mu \mathrm{M})$ for $48 \mathrm{~h}$. Kojic acid and DMSO were used as controls. MTT was added to wells $(0.625 \mathrm{mg} / \mathrm{mL}$, Sigma-Aldrich, Taufkirchen, Germany) for the last $4 \mathrm{~h}$. Then, lysing buffer was added to dissolve insoluble formazan. The absorbance was measured $(\lambda=570 \mathrm{~nm})$ using a Thermo Lab Multiscan RC microplate reader.

\subsection{Measurement of Melanin Production}

Measurement of melanin production in the B16F10 murine melanoma cell line was performed as described in our previous papers $[20,21]$. The cells were seeded into a 96-well plate $\left(5 \times 10^{3}\right.$ cells /well) and stimulated with $\alpha$-MSH ( $100 \mathrm{nM}$, Sigma-Aldrich, Taufkirchen, Germany). After $24 \mathrm{~h}$, cells were treated with the investigated thiosemicarbazones, as well as DMSO and kojic acid, at a final concentration of 100, 40, 10, 4, and $1 \mu \mathrm{M}$. After $48 \mathrm{~h}$ of incubation with inhibitors, cells were solubilized in $1 \mathrm{~N}$ sodium hydroxide $\left(1 \mathrm{~N}, 60^{\circ} \mathrm{C}\right.$, $2 \mathrm{~h}$ ). In order to measure melanin content, absorbance was measured $(\lambda=405 \mathrm{~nm})$ using a microplate reader.

Supplementary Materials: The following are available online at https:/ /www.mdpi.com/1424-824 7/14/1/74/s1: Table S1. GoldScore results for all TSCs; Section 1. Detailed description of the interaction between TSCs 1-12 and the active site of tyrosinase; Figure S1. ${ }^{1} \mathrm{H}-\mathrm{NMR}$ spectrum of mixture of (E)- and (Z)-2'-methoxyacetophenone thiosemicarbazone (TSC 1); Figure S2. Expanded aromatic region of ${ }^{1} \mathrm{H}-\mathrm{NMR}$ spectrum of mixture of $(E)$ - and $(\mathrm{Z})-2^{\prime}$-methoxyacetophenone thiosemicarbazone (TSC 1); Figure S3. Expanded aliphatic region of ${ }^{1} \mathrm{H}-\mathrm{NMR}$ spectrum of mixture of $(E)$ - and (Z)-2'methoxyacetophenone thiosemicarbazone (TSC 1); Figure $\mathrm{S} 4 .{ }^{13} \mathrm{C}\left\{{ }^{1} \mathrm{H}\right\}$-NMR spectrum of mixture of $(E)$ - and (Z)-2'-methoxyacetophenone thiosemicarbazone (TSC 1); Figure S5. Expanded aromatic region of ${ }^{13} \mathrm{C}\left\{{ }^{1} \mathrm{H}\right\}$-NMR spectrum of mixture of $(E)$ - and $(Z)-2^{\prime}$-methoxyacetophenone thiosemicarbazone (TSC 1); Figure S6. Expanded aliphatic region of ${ }^{13} \mathrm{C}\left\{{ }^{1} \mathrm{H}\right\}$-NMR spectrum of mixture of $(E)$ and (Z)-2'-methoxyacetophenone thiosemicarbazone (TSC 1); Figure S7. NOESY spectrum of the mixture of (E)- and (Z)-2'-methoxyacetophenone thiosemicarbazone (TSC 1); Figure S8. ${ }^{1} \mathrm{H}-\mathrm{NMR}$ spectrum of (E)-3'-methoxyacetophenone thiosemicarbazone (TSC 2); Figure S9. Expanded aromatic region of ${ }^{1} \mathrm{H}-\mathrm{NMR}$ spectrum of $(E)-3^{\prime}$-methoxyacetophenone thiosemicarbazone (TSC 2); Figure S10. ${ }^{1} \mathrm{H}-\mathrm{NMR}$ spectrum of (E)-4'-methoxyacetophenone thiosemicarbazone (TSC 3); Figure S11. Expanded aromatic region of ${ }^{1} \mathrm{H}$-NMR spectrum of $(E)-4^{\prime}$-methoxyacetophenone thiosemicarbazone (TSC 3); Figure S12. ${ }^{1} \mathrm{H}$-NMR spectrum of mixture of $(E)$ - and (Z)-2'-aminoacetophenone thiosemicarbazone (TSC 4); Figure S13. Expanded aromatic region of ${ }^{1} \mathrm{H}-\mathrm{NMR}$ spectrum of mixture of (E)- and (Z)-2'aminoacetophenone thiosemicarbazone (TSC 4); Figure S14. Expanded aliphatic region of ${ }^{1} \mathrm{H}-\mathrm{NMR}$ spectrum of mixture of (E)- and (Z)-2'-methoxyacetophenone thiosemicarbazone (TSC 4); Figure S15. ${ }^{13} \mathrm{C}\left\{{ }^{1} \mathrm{H}\right\}$-NMR spectrum of mixture of $(E)$ - and $(\mathrm{Z})-2^{\prime}$-aminoacetophenone thiosemicarbazone (TSC 4); Figure S16. Expanded aromatic region of ${ }^{13} \mathrm{C}\left\{{ }^{1} \mathrm{H}\right\}$-NMR spectrum of mixture of $(E)$ - and (Z)-2'-aminoacetophenone thiosemicarbazone (TSC 4); Figure S17. Expanded aliphatic region of ${ }^{13} \mathrm{C}\left\{{ }^{1} \mathrm{H}\right\}$-NMR spectrum of mixture of $(E)$ - and (Z)-2'-aminoacetophenone thiosemicarbazone (TSC 4); Figure S18. NOESY spectrum of the mixture of (E)- and (Z)-2'-aminoacetophenone thiosemicarbazone (TSC 4); Figure S19. ${ }^{1} \mathrm{H}-\mathrm{NMR}$ spectrum of mixture of $(E)-3^{\prime}$-aminoacetophenone thiosemicarbazone (TSC 5); Figure S20. Expanded aromatic region of ${ }^{1} \mathrm{H}-\mathrm{NMR}$ spectrum of (E)-3'-aminoacetophenone thiosemicarbazone (TSC 5); Figure S21. ${ }^{1} \mathrm{H}$-NMR spectrum of mixture of (E)-4'-aminoacetophenone thiosemicarbazone (TSC 6); Figure S22. Expanded aromatic region of ${ }^{1} \mathrm{H}-\mathrm{NMR}$ spectrum of $(E)$ $4^{\prime}$-aminoacetophenone thiosemicarbazone (TSC 6); Figure S23. ${ }^{1} \mathrm{H}$-NMR spectrum of mixture of (E)- and (Z)-2'-hydroxyacetophenone thiosemicarbazone (TSC 7); Figure S24. Expanded aromatic region of ${ }^{1} \mathrm{H}$-NMR spectrum of mixture of $(E)$ - and (Z)-2'-hydroxyacetophenone thiosemicarbazone (TSC 7); Figure S25. Expanded aliphatic region of ${ }^{1} \mathrm{H}-\mathrm{NMR}$ spectrum of mixture of (E)- and (Z)-2'hydroxyacetophenone thiosemicarbazone (TSC 7); Figure S26. ${ }^{13} \mathrm{C}$-NMR spectrum of mixture of $(E)$ and (Z)-2'-hydroxyacetophenone thiosemicarbazone (TSC 7); Figure S27. Expanded aromatic region of ${ }^{13} \mathrm{C}-\mathrm{NMR}$ spectrum of mixture of $(E)$ - and (Z)-2'-hydroxyacetophenone thiosemicarbazone (TSC 7); Figure S28. NOESY spectrum of mixture of $(E)$ - and (Z)-2'-hydroxyacetophenone thiosemicar- 
bazone (TSC 7); Figure S29. ${ }^{1} \mathrm{H}-\mathrm{NMR}$ spectrum of methanol solvate of (E)-3'-hydroxyacetophenone thiosemicarbazone (TSC $8 \bullet \mathrm{CH}_{3} \mathrm{OH}$ ); Figure S30. Expanded aromatic region of ${ }^{1} \mathrm{H}-\mathrm{NMR}$ spectrum of methanol solvate of (E)-3'-hydroxyacetophenone thiosemicarbazone (TSC $\left.8 \bullet \mathrm{CH}_{3} \mathrm{OH}\right)$; Figure S31. ${ }^{13} \mathrm{C}-\mathrm{NMR}$ spectrum of methanol solvate of $(E)$-3'-hydroxyacetophenone thiosemicarbazone (TSC $8 \bullet \mathrm{CH}_{3} \mathrm{OH}$ ); Figure S32. Expanded aromatic region of ${ }^{13} \mathrm{C}$-NMR spectrum of methanol solvate of (E)-3'-hydroxyacetophenone thiosemicarbazone (TSC $8 \bullet \mathrm{CH}_{3} \mathrm{OH}$ ); Figure S33. ${ }^{1} \mathrm{H}-\mathrm{NMR}$ spectrum of (E)-4'-hydroxyacetophenone thiosemicarbazone (TSC 9); Figure S34. Expanded aromatic region of ${ }^{1} \mathrm{H}-\mathrm{NMR}$ spectrum of (E)-4'-hydroxyacetophenone thiosemicarbazone (TSC 9); Figure S35. ${ }^{1} \mathrm{H}-\mathrm{NMR}$ spectrum of (E)-2'-nitroacetophenone thiosemicarbazone (TSC 10); Figure S36. Expanded aromatic region of ${ }^{1} \mathrm{H}-\mathrm{NMR}$ spectrum of $(E)-2^{\prime}$-nitroacetophenone thiosemicarbazone (TSC 10); Figure S37. ${ }^{1} \mathrm{H}-\mathrm{NMR}$ spectrum of (E)-3'-nitroacetophenone thiosemicarbazone (TSC 11); Figure S38. Expanded aromatic region of ${ }^{1} \mathrm{H}-\mathrm{NMR}$ spectrum of $(E)$-3'-nitroacetophenone thiosemicarbazone (TSC 11); Figure S39. ${ }^{1} \mathrm{H}$-NMR spectrum of (E)-4'-nitroacetophenone thiosemicarbazone (TSC 12); Figure S40. Expanded aromatic region of ${ }^{1} \mathrm{H}-\mathrm{NMR}$ spectrum of $(E)-4^{\prime}$-nitroacetophenone thiosemicarbazone (TSC 12); Section 2. Enzyme preparation.

Author Contributions: K.H. isolated the enzyme, and performed enzyme studies and molecular docking; N.A.-G. and J.R. performed the experiments on B16F10 cells; W.G. performed synthesis and wrote the chemical part of the manuscript; K.H. analyzed the data and wrote the manuscript; R.L. supervised the project and edited the manuscript. All authors have read and agreed to the published version of the manuscript.

Funding: This research was funded by the Wroclaw Center of Biotechnology program, The Leading National Research Center (KNOW) for years 2014-2018, and the Polish Ministry of Science and Higher Education (PMSHE) for the Faculty of Chemistry of Wrocław University of Science and Technology. The molecular modeling was carried out using hardware and software resources of The Supercomputing and Networking Center in Wroclaw (grant no. 197).

Data Availability Statement: The data presented in this study are available in the main text and Supplementary Materials.

Acknowledgments: W.G. thanks Gabriela Maciejewska for recording the HRMS spectra and Pawel Dabrowski for recording the NMR spectra.

Conflicts of Interest: The authors declare no conflict of interest. The funders had no role in the design of the study; in the collection, analyses, or interpretation of data; in the writing of the manuscript, or in the decision to publish the results.

\section{References}

1. Siegbahn, P.E.R. The catalytic cycle of tyrosinase: Peroxide attack on the phenolate ring followed by O[bond]O cleavage. J. Biol. Inorg. Chem. 2003, 8, 567-576. [CrossRef] [PubMed]

2. Claus, H.; Decker, H. Bacterial tyrosinases. Syst. Appl. Microbiol. 2006, 29, 3-14. [CrossRef]

3. D'Ischia, M.; Wakamatsu, K.; Cicoira, F.; Di Mauro, E.; Garcia-Borron, J.C.; Commo, S.; Galvan, I.; Ghanem, G.; Kenzo, K.; Meredith, P.; et al. Melanins and melanogenesis: From pigment cells to human health and technological applications. Pigm. Cell Melanoma R 2015, 28, 520-544. [CrossRef] [PubMed]

4. Hridya, H.; Amrita, A.; Mohan, S.; Gopalakrishnan, M.; Dakshinamurthy, T.K.; Doss, G.P.; Siva, R. Functionality study of santalin as tyrosinase inhibitor: A potential depigmentation agent. Int. J. Biol. Macromol. 2016, 86, 383-389. [CrossRef] [PubMed]

5. Xu, H.; Zhang, X.; Karangwa, E.; Xia, S. Correlating enzymatic browning inhibition and antioxidant ability of Maillard reaction products derived from different amino acids. J. Sci. Food Agric. 2017, 97, 4210-4218. [CrossRef]

6. Pillaiyar, T.; Manickam, M.; Namasivayam, V. Skin whitening agents: Medicinal chemistry perspective of tyrosinase inhibitors. Enzym. Inhib. Med. Chem. 2017, 32, 403-425. [CrossRef]

7. Pillaiyar, T.; Manickam, M.; Jung, S.H. Inhibitors of Melanogenesis: An Updated Review. J. Med. Chem. 2018, 61, 7395-7418. [CrossRef]

8. Lee, S.Y.; Baek, N.; Nam, T.G. Natural, semisynthetic and synthetic tyrosinase inhibitors. J. Enzym. Inhib. Med. Chem. 2016, 31, 1-13. [CrossRef]

9. Burnett, C.L.; Bergfeld, W.F.; Belsito, D.V.; Hill, R.A.; Klaassen, C.D.; Liebler, D.C.; Marks, J.G., Jr.; Shank, R.C.; Slaga, T.J.; Snyder, P.W.; et al. Final report of the safety assessment of Kojic acid as used in cosmetics. Int. J. Toxicol. 2010, 29, 244S-273S. [CrossRef]

10. Andersen, F.A.; Bergfeld, W.F.; Belsito, D.V.; Hill, R.A.; Klaassen, C.C.D.; Liebler, D.C.; Marks, J.G., Jr.; Shank, R.C.; Slaga, T.J.; Snyder, P.W. Final amended safety assessment of hydroquinone as used in cosmetics. Int. J. Toxicol. 2010, 29 (Suppl. 6), 274S-287S. [CrossRef] 
11. Yusuf, M.; Jain, P. Synthesis and biological significances of 1,3,4-thiadiazolines and related heterocyclic compounds. Arab. J. Chem. 2014, 7, 525-552. [CrossRef]

12. Chellan, P.; Nasser, S.; Vivas, L.; Chibale, K.; Smith, G.S. Cyclopalladated complexes containing tridentate thiosemicarbazone ligands of biological significance: Synthesis, structure and antimalarial activity. J. Organomet. Chem. 2010, 695, 2225-2232. [CrossRef]

13. Yu, Y.; Suryo Rahmanto, Y.; Richardson, D.R. Bp44mT: An orally active iron chelator of the thiosemicarbazone class with potent anti-tumour efficacy. Br. J. Pharmacol. 2012, 165, 148-166. [CrossRef] [PubMed]

14. Arslan, H.; Duran, N.; Borekci, G.; Ozer, C.K.; Akbay, C. Antimicrobial Activity of Some Thiourea Derivatives and Their Nickel and Copper Complexes. Molecules 2009, 14, 519-527. [CrossRef]

15. Song, S.; You, A.; Chen, Z.; Zhu, G.; Wen, H.; Song, H.; Yi, W. Study on the design, synthesis and structure-activity relationships of new thiosemicarbazone compounds as tyrosinase inhibitors. Eur. J. Med. Chem. 2017, 139, 815-825. [CrossRef]

16. You, A.; Zhou, J.; Song, S.; Zhu, G.; Song, H.; Yi, W. Structure-based modification of 3-/4-aminoacetophenones giving a profound change of activity on tyrosinase: From potent activators to highly efficient inhibitors. Eur. J. Med. Chem. 2015, 93, 255-262. [CrossRef]

17. Buitrago, E.; Vuillamy, A.; Boumendjel, A.; Yi, W.; Gellon, G.; Hardré, R.; Philouze, C.; Serratrice, G.; Jamet, H.; Regliér, M.; et al. Exploring the Interaction of N/S Compounds with a Dicopper Center: Tyrosinase Inhibition and Model Studies. Inorg. Chem. 2014, 53, 12848-12858. [CrossRef]

18. You, A.; Zhou, J.; Song, S.; Zhu, G.; Song, H.; Yi, W. Rational design, synthesis and structure-Activity relationships of 4-alkoxyand 4-acyloxy-phenylethylenethiosemicarbazone analogues as novel tyrosinase inhibitors. Bioorg. Med. Chem. 2015, 23, 924-931. [CrossRef]

19. Yang, M.H.; Chen, C.M.; Hu, Y.H.; Zheng, C.Y.; Li, Z.C.; Ni, L.L.; Sun, L.; Chen, Q.X. Inhibitory kinetics of DABT and DABPT as novel tyrosinase inhibitors. J. Biosci. Bioeng. 2013, 115, 514-517. [CrossRef]

20. Hałdys, K.; Goldeman, W.; Jewgiński, M.; Wolińska, E.; Anger, N.; Rossowska, J.; Latajka, R. Inhibitory properties of aromatic thiosemicarbazones on mushroom tyrosinase: Synthesis, kinetic studies, molecular docking and effectiveness in melanogenesis inhibition. Bioorg. Chem. 2018, 81, 577-586. [CrossRef]

21. Hałdys, K.; Goldeman, W.; Jewgiński, M.; Wolińska, E.; Anger, N.; Rossowska, J.; Latajka, R. Halogenated aromatic thiosemicarbazones as potent inhibitors of tyrosinase and melanogenesis. Bioorg. Chem. 2020, 94, 10341. [CrossRef] [PubMed]

22. Xie, J.; Dong, H.; Yu, Y.; Cao, S. Inhibitory effect of synthetic aromatic heterocycle thiosemicarbazone derivatives on mushroom tyrosinase: Insights from fluorescence, ${ }^{1} \mathrm{H}$ NMR titration and molecular docking studies. Food Chem. 2016, 190, 709-716. [CrossRef] [PubMed]

23. Dong, H.; Liu, J.; Liu, X.; Yu, Y.; Cao, S. Combining molecular docking and QSAR studies for modeling the anti-tyrosinase activity of aromatic heterocycle thiosemicarbazone analogues. J. Mol. Struct. 2018, 1151, 353-365. [CrossRef]

24. Makam, P.; Kankanala, R.; Prakash, A.; Kannan, T. 2-(2-Hydrazinyl)thiazole derivatives: Design, synthesis and in vitro antimycobacterial studies. Eur. J. Med. Chem. 2013, 69, 564-576. [CrossRef] [PubMed]

25. Opletalová, V.; Kalinowski, D.S.; Vejsová, M.; Kuneš, J.; Pour, M.; Jampílek, J.; Buchta, V.; Richardson, D.S. Identification and Characterization of Thiosemicarbazones with Antifungal and Antitumor Effects: Cellular Iron Chelation Mediating Cytotoxic Activity. Chem. Res. Toxicol. 2008, 21, 878-1889. [CrossRef]

26. Ali, A.A.; Nimir, H.; Aktas, C.; Huch, V.; Rauch, U.; Schäfer, K.H.; Veith, M. Organoplatinum(II) Complexes with 2Acetylthiophene Thiosemicarbazone: Synthesis, Characterization, Crystal Structures, and in Vitro Antitumor Activity. Organometallics 2012, 31, 2256-2262. [CrossRef]

27. Fatondji, H.R.; Kpoviessi, S.; Gbaguidi, F.; Bero, J.; Hannaert, V.; Quetin-Leclercq, J.; Poupaert, J.; Moudachirou, M.; Accrombessi, G.C. Structure-activity relationship study of thiosemicarbazones on an African trypanosome: Trypanosoma brucei brucei. Med. Chem. Res. 2013, 22, 2151-2162. [CrossRef]

28. Thanigaimalai, P.; Lee, K.C.; Sharma, V.K.; Roh, E.; Kim, Y.; Jung, S.H. Ketonethiosemicarbazones: Structure-activity relationships for their melanogenesis inhibition. Bioorg. Med. Chem. Lett. 2011, 21, 3527-3530. [CrossRef]

29. Chang, T.S. An Updated Review of Tyrosinase Inhibitors. Int. J. Mol. Sci. 2009, 10, 2440-2475. [CrossRef]

30. Chen, J.S.; Wei, C.I.; Marshall, M.R. Inhibition mechanism of kojic acid on polyphenol oxidase. J. Agric. Food Chem. 1991, 39, 1897-1901. [CrossRef]

31. Copeland, R.A. Enzymes: A Practical Introduction to Structure, Mechanism, and Data Analysis, 2nd ed.; Viley-VCH: New York, NY, USA, 2000.

32. Ismaya, W.T.; Rozeboom, H.J.; Weijn, A.; Fusetti, F.; Wichers, H.J.; Dijkstra, B.W. Crystal structure of Agaricus bisporus mushroom tyrosinase: Identity of the tetramer subunits and interaction with tropolone. Biochemistry 2011, 50, 5477-5486. [CrossRef] [PubMed]

33. Jones, G.; Willett, P.; Glen, R.C.; Leach, A.R.; Taylor, R. Development and validation of a genetic algorithm for flexible docking. J. Mol. Biol. 1997, 267, 727-748. [CrossRef] [PubMed]

34. BIOVIA Discovery Studio Visualizer 5; Dassault Systèmes: San Diego, CA, USA, 2018.

35. Zhu, T.H.; Cao, S.W.; Yu, Y.Y. Synthesis, characterization and biological evaluation of paeonol thiosemicarbazone analogues as mushroom tyrosinase inhibitors. Int. J. Biol. Macromol. 2013, 62, 589-595. [CrossRef] [PubMed] 
36. Parvez, S.; Kang, M.; Chung, H.S.; Bae, H. Naturally occurring tyrosinase inhibitors: Mechanism and applications in skin health, cosmetics and agriculture industries. Phythoter. Res. 2007, 21, 805-816. [CrossRef] [PubMed]

37. Bagherzadeh, K.; Talari, F.S.; Sharifi, A.; Ganjali, M.R.; Saboury, A.A.; Amanlou, M. A new insight into mushroom tyrosinase inhibitors: Docking, pharmacophore-based virtual screening, and molecular modeling studies. J. Biomol. Struct. Dyn. 2015, 33, 487-501. [CrossRef] [PubMed]

38. Briganti, S.; Camera, E.; Picardo, M. Chemical and instrumental approaches to treat hyperpigmentation. Pigm. Cell Res. 2003, 16, 101-110. [CrossRef]

39. Solano, F.; Briganti, S.; Picardo, M.; Ghanem, G. Hypopigmenting agents: An updated review on biological, chemical and clinical aspects. Pigm. Cell Res. 2006, 19, 550-571. [CrossRef]

40. Du, X.H.; Guo, C.; Hansell, E.; Doyle, P.S.; Caffrey, C.R.; Holler, T.P.; McKerrow, J.H.; Cohen, F.E. Synthesis and structure-activity relationship study of potent trypanocidal thiosemicarbazone inhibitors of the trypanosomal cysteine protease cruzain. J. Med. Chem. 2002, 45, 2695-2707. [CrossRef]

41. Saravanan, R.R.; Seshadri, S.; Gunasekaran, S.; Mendoza-Merońo, R.; Garcia-Granda, S. Conformational analysis, X-ray crystallographic, FT-IR, FT-Raman, DFT, MEP and molecular docking studies on 1-(1-(3-methoxyphenyl) ethylidene) thiosemicarbazide. Spectrochim. Acta A Mol. Biomol. Spectrosc. 2015, 139, 321-328. [CrossRef]

42. Greenbaum, D.C.; Mackey, Z.; Hansell, E.; Doyle, P.; Gut, J.; Caffrey, C.R.; Lehrman, J.; Rosenthal, P.J.; McKerrow, J.H.; Chibale, K. Synthesis and Structure-Activity Relationships of Parasiticidal Thiosemicarbazone Cysteine Protease Inhibitors against Plasmodium falciparum, Trypanosoma brucei, and Trypanosoma cruzi. J. Med. Chem. 2004, 47, 3212-3219. [CrossRef]

43. Blau, L.; Menegon, R.F.; Trossini, G.H.G.; Molino, J.V.D.; Vital, D.G.; Cicarelli, R.M.B.; Passerini, G.D.; Bosquesi, P.L.; Chin, C.M. Design, synthesis and biological evaluation of new aryl thiosemicarbazone as antichagasic candidates. Eur. J. Med. Chem. 2013, 67, 142-151. [CrossRef] [PubMed]

44. Singh, V.P.; Singh, R.V.; Tandon, J.P. Synthetic and structural studies of some tetracoordinated boron complexes of bifunctional tridentate Schiff bases. J. Prakt. Chem. 1989, 331, 690-696. [CrossRef]

45. Liu, J.; Yi, W.; Wan, Y.; Ma, L.; Song, H. 1-(1-Arylethylidene)thiosemicarbazide derivatives: A new class of tyrosinase inhibitors. Bioorg. Med. Chem. 2008, 16, 1096-1102. [CrossRef] [PubMed]

46. Murakata, C.; Yamashita, Y.; Nakai, R.; Akasaka, K.; Ino, Y.; Kato, K.; Kitamura, Y. M-Stage Kinesin inhibitor. European Patent Application EP1616866, 18 January 2006.

47. Prabhu, R.N.; Pandiarajan, D.; Ramesh, R. Ruthenium(II) mediated C-H activation of substituted acetophenone thiosemicarbazones: Synthesis, structural characterization, luminescence and electrochemical properties. J. Organomet. Chem. 2009, 694, 4170-4177. [CrossRef]

48. Gasowska, B.; Kafarski, P.; Wojtasek, H. Interaction of mushroom tyrosinase with aromatic amines, o-diamines and o-aminophenols. BBA Gen. Subj. 2004, 1673, 170-177. [CrossRef]

49. Labus, K. Biotransformacje z Wykorzystaniem Tyrozynazy z Agaricus Bisporus w Formie Natywnej i Immobilizowanej. Ph.D. Thesis, Wrocław University of Science and Technology, Wrocław, Poland, 2011.

50. Zynek, K.; Bryjak, J. Isolation and purification of tyrosinase from Agaricus bisporus. Inz. Aparat. Chem. 2009, 3, $125-126$.

51. Frisch, M.J.; Trucks, G.W.; Schlegel, H.B.; Scuseria, G.E.; Robb, M.A.; Cheeseman, J.R.; Scalmani, G.; Barone, V.; Mennucci, B.; Petersson, G.A.; et al. Gaussian 09, Revision, D.01; Fox, Gaussian, Inc.: Wallingford, CT, USA, 2013.

52. Tomasi, J.; Mennucci, B.; Cammi, R. Quantum mechanical continuum solvation models. Chem. Rev. 2005, 105, 2999-3093. [CrossRef] [PubMed]

53. H++. Available online: http://biophysics.cs.vt.edu/index.php (accessed on 12 May 2019).

54. Anandakrishnan, R.; Aguilar, B.; Onufriev, A.V. H++ 3.0: Automating pK prediction and the preparation of biomolecular structures for atomistic molecular modeling and simulation. Nucleic Acids Res. 2012, 40, 537-541. [CrossRef]

55. Myers, J.; Grothaus, G.; Narayanan, S.; Onufriev, A. A simple clustering algorithm can be accurate enough for use in calculations of pKs in macromolecules. Proteins 2006, 63, 928-938. [CrossRef]

56. Gordon, J.C.; Myers, J.B.; Folta, T.; Shoja, V.; Heath, L.S.; Onufriev, A. H++: A server for estimating pKas and adding missing hydrogens to macromolecules. Nucleic Acids Res. 2005, 33, W368-W371. [CrossRef]

57. GOLD; 5.5 Version; CCDC: Cambridge, UK.

58. Azam, S.S.; Uddin, R.; Syed, A.A.S.; Ul-Haq, Z. Molecular docking studies of potent inhibitors of tyrosinase and $\alpha$-glucosidase. Med. Chem. Res. 2012, 21, 1677-1683. [CrossRef]

59. Bellei, B.; Pitisci, A.; Izzo, E.; Picardo, M. Inhibition of Melanogenesis by the Pyridinyl Imidazole Class of Compounds: Possible Involvement of the Wnt/ $\beta$-Catenin Signaling Pathway. PLoS ONE 2012, 7, e33021. [CrossRef] [PubMed] 